\title{
Stranding, weak pronouns, and the fine structure of the Dutch Mittelfeld
}

\author{
E.G. Ruys
}

Received: 3 February 2006 / Accepted: 22 March 2007 / Published online: 9 September 2008

(C) The Author(s) 2008. This article is published with open access at Springerlink.com

\begin{abstract}
The purpose of this paper is to develop a tool for determining the unmarked position of various PP types in the Dutch Mittelfeld. The paper argues that the distribution of stranded prepositions, which obey a Freezing constraint, can be used for this purpose, and that the same holds for prepositions with a weak pronominal complement. Among the results of this twin diagnostic are independent evidence for a case-movement analysis of scrambling, and support for a particular analysis of predicative complement constructions.
\end{abstract}

Keywords Preposition stranding · Weak pronouns · PP scrambling · Middlefield · Cartography

\section{Introduction}

Consider the Dutch data in (1)-(3):

(1) a. dat Jan niet [PP op deze beslissing] had gerekend that Jan not on this decision had counted

b. dat Jan [PP op deze beslissing] niet had gerekend that Jan on this decision not had counted

(2) a. de beslissing waar ${ }_{i}$ Jan niet [PP $t_{i}$ op] had gerekend the decision which Jan not on had counted

b. * de beslissing waar $_{\mathrm{i}} \operatorname{Jan}_{[\mathrm{PP}} \mathrm{t}_{\mathrm{i}}$ op] niet had gerekend the decision which Jan on not had counted

E.G. Ruys (凶)

UiL-OTS, Utrecht University, 3512 JK, Utrecht, The Netherlands

e-mail: eddy.ruys@let.uu.nl 
(3) a. dat Jan niet [PP op ze] had gerekend that Jan not on them had counted

b. * dat Jan [PP op ze] niet had gerekend that Jan on them not had counted

As (1) illustrates, a given PP is often free to occur in various positions in the Dutch Mittelfeld. Preposition Stranding, however, is generally allowed from only one of these positions, as (2) shows. Various accounts of this restriction have been proposed. Some claim that stranded P must be V-adjacent; others argue that once a PP has moved, it is "frozen". The present paper argues for a new empirical generalization: with some provisos, the distribution of stranded $\mathrm{P}$ mirrors the distribution of $\mathrm{P}$ with a weak pronoun as its complement, as shown in (3). I call this the "[ $\mathrm{P} x \mathrm{x}]$ generalization."

If correct, the [ $\mathrm{P} x$ ] generalization has various theoretical and analytical consequences. First of all, it can be employed to argue decisively against a V-adjacency account of both distribution patterns, in favor of a Freezing account. It will also help determine the correct explanation of the freezing effect. Analytically, the generalization can be employed as a tool for establishing the unmarked (hence, I will argue, base-generated) position of various PP types, and of other elements in the Dutch Mittelfeld, in finer detail than has previously been achieved. This is helpful, since the considerable surface variation within the Dutch Mittelfeld often makes it difficult to determine in which order its constituents are base-generated. In particular, I will show how the [ $\mathrm{P} \mathrm{x}$ ] generalization can be used to support a cartography of PP positions, and to resolve the intricate and puzzling word-order phenomena found with P-stranding in predicative complement constructions, which are summarized in (4). In the unmarked word order, PP adverbials follow AP predicates, but precede PP predicates, except that: prosodically light APs may follow the adverbial, and heavy adverbials precede all predicates.

\section{(4) $\mathrm{PP}_{\text {Adv:heavy }} \mathrm{AP}_{\text {Pred }} \mathrm{PP}_{\text {Adv:light }} \mathrm{PP}_{\text {Pred }} / \mathrm{AP}_{\text {Pred:light }} \mathrm{V}$}

These findings also provide new support for the theory that both (DP) arguments and (AP) predicates undergo obligatory movement in the Dutch Mittelfeld. The resulting analysis ends up explaining facts that were previously taken to support the $\mathrm{V}$-adjacency account of P-stranding. The [ $\mathrm{P} \mathrm{x}]$ generalization proposed here extends existing work on the relation between pronoun distribution and stranding (Ross 1967; Abels 2003) in a new direction.

The remainder of the paper is organized as follows. Section 1 sketches the distribution of stranded prepositions and of prepositions with weak pronominal complements, states the [ $\mathrm{P} \mathrm{x}$ ] generalization, and discusses its theoretical implications. Section 2 presents empirical support; it yields descriptive results concerning the base positions of various PP types and other material in the Dutch Mittelfeld, and serves to establish the reliability of the proposed method of determining the unmarked positions of PPs, and to explore its limitations. Sections 3 and 4 use this method to explore the structure and underlying order of predicative complement constructions. 


\section{Two diagnostics: stranding and weak pronouns}

In this section, I will that argue that the distribution of stranded prepositions and prepositions with weak pronominal complements can be used to detect the unmarked position of PPs in Dutch. Section 1.1 argues for the initial plausibility of the P-stranding test. Section 1.2 argues that prepositions with weak pronominal complements can also be used for this purpose, and introduces the [ P x ] generalization: stranded $\mathrm{P}$ has the same distribution as $\mathrm{P}$ with weak pronominal complement.

\subsection{PP movement and P-stranding}

There are several broad generalizations governing P-stranding in English and Dutch. First, grammatical function plays a role. For instance, locative and temporal adjunct PPs typically disallow stranding in English, as observed by Ross (1967) (see also Hornstein and Weinberg 1981), whereas, e.g., instrumental adjunct PPs and argument PPs allow stranding. The same contrast is found in Dutch. Van Riemsdijk (1978: 26) suggested an account in terms of the (semantic) closeness of the PP to the main verb; an explanation in terms of structural conditions on extraction was proposed in Bennis and Hoekstra (1984), Bennis (1986), and Koster (1987). A second generalization, partly treatable as a corollary of the first, is that only a subclass of prepositions ever allow stranding; e.g., such prepositions as despite or since never do. See Zwarts (1997) for an inventory of Dutch prepositions that allow and disallow stranding. Third, a restriction that holds in Dutch, but not English, is that only adpositions in their postpositional use allow stranding; or, nearly equivalently, that only pronominals of the $+\mathrm{R}$ class, which trigger the postpositional use of the adposition, allow stranding:
a. Jan rekent [PP daar $_{[+\mathrm{R}]}$ op $]$.
Jan counts that $[+R]$ on
'Jan counts on that.'
b. $\operatorname{Waar}_{[+\mathrm{R}] \mathrm{i}} / *_{\mathrm{wat}_{[-\mathrm{R}] \mathrm{i}}}$ rekent Jan [PP $\mathrm{t}_{\mathrm{i}}$ op ]? what $_{[+\mathrm{R}]} /$ what $[-\mathrm{R}]$ counts Jan on 'What does Jan count on?'
c. dat Jan daar $_{[+\mathrm{R}] \mathrm{i}} / \mathrm{er}_{[+\mathrm{R}] \mathrm{i}}$ vaak [PP $\mathrm{t}_{\mathrm{i}}$ op] rekent that Jan that $[+R] / \mathrm{it}_{[+\mathrm{R}]}$ often on counts 'that Jan often counts on that/it'

Also, Dutch shows stranding only with A'-movement: movement to Spec,CP as in (5b), or "R-movement" (cliticization or scrambling of a $+\mathrm{R}$ element, as identified in Van Riemsdijk 1978) as in (5c), not with A-movement like in English pseudopassives (Van Riemsdijk 1978, pace Horst 1980). See Van Riemsdijk (1978) and Broekhuis (2002) for extensive discussion of these and further restrictions on Dutch P-stranding.

In the present paper, I will not be attempting to explain any of the factors affecting P-stranding mentioned so far. I will keep these factors constant, and limit attention to PPs which meet all of the above-mentioned conditions on P-stranding. I will vary only one additional factor: the position of the PP in the clause. It was observed by 
Hornstein and Weinberg (1981) that PPs that have undergone movement do not allow stranding: ${ }^{1}$

(6) a. Who did Pugsley give a book $<$ to $t_{i}>$ yesterday $<*$ to $t_{i}>$ ?

b. Who did John talk $<$ to $\mathrm{t}_{\mathrm{i}}>$ about Harry $<*$ to $_{\mathrm{i}}>$ yesterday?

After PP-extraposition (6a), or VP-internal PP-scrambling (6b), stranding is no longer allowed.

Similar observations hold for Dutch. When a PP can appear in various positions in the clause, only one of these positions allows stranding. Thus, PP-extraposition (“PP-over-V": Koster 1973, 1974, 1975) blocks P-stranding (Koster 1978: 104):

(7) a. dat Jan $<$ [pp op de beslissing ] $>$ wacht $<$ [PP op de beslissing ] $>$ that Jan $<$ for the decision $>\quad$ waits $<$ for the decision $>$

b. de beslissing waar wan $_{\mathrm{i}} \quad\left[\mathrm{pP} \mathrm{t}_{\mathrm{i}}\right.$ op $]>$ wacht $<*\left[\mathrm{pP} \mathrm{t}_{\mathrm{i}}\right.$ op $]>$ the decision which $_{[+\mathrm{R}]}$ Jan $<$ for $>$ waits $<$ for $>$

The same holds for PP scrambling. PPs scramble relatively freely in Dutch: PP arguments and adjuncts vary in position with adverbs, negation, objects, and each other (see, e.g., Koster 1974; Helmantel 2002). But only one of the various positions in which a given PP can occur allows stranding. This is illustrated by (2) above, and again by (8):

(8) a. dat Jan <aan ieder meisje> een boek <aan ieder meisje> gaf that Jan <to every girl> a book <to every girl $>$ gave

b. het meisje waar Jan $_{\mathrm{i}}<\left[{ }_{\mathrm{PP}} \mathrm{t}_{\mathrm{i}}\right.$ aan $]>$ een boek $<\left[\mathrm{PP}_{\mathrm{i}}\right.$ aan $]>$ gaf the girl which $_{[+\mathrm{R}]}$ Jan $<$ to $>$ a book $<$ to $>$ gave

Two basic descriptive generalizations have been proposed to capture these facts. One description is that stranded P in Dutch must be left-adjacent to V. Another description states that P may strand only if PP has not moved. I will briefly discuss both options, and explain why I opt for the latter.

One description of the observations in (7)-(8) is that stranded P must be leftadjacent to V (see, e.g., Hoekstra 1979; Bennis and Hoekstra 1984; Bennis 1986; Broekhuis 2002). This generalization in turn has received various explanations. For instance, Bennis and Hoekstra (1984) and Bennis (1986) adopt an ECP-type requirement (a variant of the one in Kayne 1984) which allows extraction from PP only if PP is canonically governed (minimally c-commanded) by $\mathrm{V}$; in a binary branching structure this entails string-adjacency of PP to the base position of $\mathrm{V}^{2}$ Hoekstra (1979) suggested it is not PP that must be adjacent to V, but stranded P itself: without venturing a deeper explanation, he assumed that the $\mathrm{V}$-adjacency requirement can be

\footnotetext{
${ }^{1}$ Notation: when $\mathrm{X}$ must occur in one place in the structure, I write $<\mathrm{X}>$ to indicate a position where $\mathrm{X}$ may occur, and $<* X>$ to indicate a position where it may not.

${ }^{2}$ An ECP based account of Dutch P-stranding that requires proximity of PP to $\mathrm{V}$ is proposed also by Van Riemsdijk and Williams (1986). Stowell (1982) explains the adjacency requirement in Dutch P-stranding by setting adjacency as a precondition for Reanalysis; Reanalysis in turn is required for the trace in a stranding structure to obey the ECP, as originally proposed in Kayne (1984).
} 
met by $\mathrm{P}$ rightward moving to $\mathrm{V}{ }^{3}$ Two observations seemed to justify this assumption: stranded $\mathrm{P}$ may occur in between direct object and V as in (9a), obviously a derived order; and stranded $\mathrm{P}$ may occur left-adjacent to $\mathrm{V}$ in structures $(9 \mathrm{~b})$ where the corresponding full PP may not (9c):
a. het glas waar Jan wijn uit drinkt
the glass which Jan wine from drinks
b. de schoenen waar Jan naar Amsterdam mee loopt the shoes which Jan to Amsterdam with walks
c. * dat Jan naar Amsterdam [PP met die schoenen] loopt that Jan to Amsterdam with those shoes walks

The major problem facing the $\mathrm{V}$-adjacency generalization is that several classes of counterexamples have been identified. Hoekstra (1979), Bennis and Hoekstra (1984), and Bennis (1986) already mentioned several types of elements that may occur between stranded $\mathrm{P}$ and $\mathrm{V}$ : inherent adverbs of place and direction (10a); predicative complements (10b); particles (10c).

$$
\begin{aligned}
& \text { a. de trein waar } i \mathrm{ik}\left[\mathrm{PP}_{\mathrm{i}}\right. \text { mee] naar Groningen ga } \\
& \text { the train which I with to Groningen go } \\
& \text { b. het middel } \text { waar }_{i} \mathrm{ik} \text { de kamer [PP } t_{i} \text { mee] schoon maak } \\
& \text { the product which I the room with clean make } \\
& \text { c. de trein waar } i_{i} \mathrm{ikp}_{\mathrm{p}} \mathrm{t}_{\mathrm{i}} \text { mee] terug ga } \\
& \text { the train which I with back go }
\end{aligned}
$$

These counterexamples show predicative interveners, which I will discuss further in Sects. 3 and 4. Section 2 below will present additional types of counterexamples. I will conclude that material may freely intervene between stranded $\mathrm{P}$ and $\mathrm{V}$, as long as PP remains in its unmarked (base-generated) position.

This brings me to the second descriptive generalization covering the observations in (7)-(8): P may strand only if PP has not moved. This is known as the "Freezing" hypothesis. ${ }^{4}$ Koster (1978: 103ff) first suggested that P-stranding is blocked if PP is in a marked position. For English, a Freezing account of P-stranding was proposed by Hornstein and Weinberg (1981). And for Dutch, Koster (1987: 180ff) argued against the $\mathrm{V}$-adjacency generalization on the basis of examples like (10a), and proposed as a constraint that PP may not be extracted from when moved. This blocks (7) and (8)

\footnotetext{
${ }^{3}$ A rightward movement account of P-stranding had been proposed before: Sturm and Kerstens (1978) proposed that $\mathrm{P}$-stranding consists of $\mathrm{P}$ incorporating into $\mathrm{V}$, followed by movement of the beheaded PP. Van Riemsdijk (1978) had proposed that in those (rare) cases where a non-R-pronoun strands P, P has rightward moved out of PP and thereby rendered PP transparent for extraction. A P-movement account has also been offered by Neeleman (1994) and Zwart (1993): both are discussed further in Sects. 3 and 4 below. One counterargument to the incorporation analysis, due to Koster (1987: 181), is that stranded P does not move along with V-Raising in clause-union constructions (Evers 1975); see Neeleman (1994: 65, fn 3 ) for discussion.

${ }^{4}$ It differs from the "Freezing Principle" of Culicover and Wexler (1977) (traceable to Ross 1967), which holds that movement of A to a non-base position in XP will also freeze B in XP. See Hoekstra (1979) for a discussion of Culicover and Wexler's Freezing in the context of Dutch P-stranding; see also Neeleman (1994: Ch. 2).
} 
(on the assumption that these involve PP-movement; see Sect. 2 below for further discussion of PP-over-V) while allowing (10), given reasonable assumptions regarding the underlying orders.

Counterexamples such as (10), and those in the following sections, argue directly against the $\mathrm{V}$-adjacency generalization. In addition, I will argue in the following sections that explanations of the constraints on P-stranding based on V-adjacency do not extend naturally to the constraints on $\mathrm{P}$ with a weak pronominal complement (the [ $\mathrm{P} x$ ] generalization), whereas an explanation based on Freezing that I will suggest, does. Accordingly, I assume the descriptive generalization (11), based on Koster (1978):

(11) Freezing: P-stranding is blocked if PP has undergone optional movement to a marked position.

Of course, the facts in (9), which appear to support V-adjacency, now require an alternative explanation, which the analysis in Sects. 2 through 4 will provide.

Explaining the Freezing generalization is not my primary concern here, so long as the effect can be used to test for the unmarked position of PPs. For this reason, I will not review the various proposals offered in the literature (see Corver 2006 for an overview). ${ }^{5}$ Briefly, it seems that a general constraint on movement out of moved constituents cannot be maintained (for instance, wat voor-split is allowed with scrambled DPs, see Neeleman 1994), while a specialized constraint on movement out of moved PPs would lack explanatory value. More importantly in the present context: I am not aware of an existing account that extends to the Freezing effect with weak pronouns (i.e., the [ $\mathrm{P} x$ ] generalization). To demonstrate that the generalization can be captured, I want to suggest the following explanation for the Freezing effect.

Positional variation or scrambling within the Mittelfeld in general affects the information structure of the sentence. This is well known and widely studied for DP-

\footnotetext{
${ }^{5}$ To mention just a few that concentrate on freezing effects with P-stranding: Hornstein and Weinberg's (1981) original account in terms of verb Reanalysis (Chomsky 1974), like Culicover and Wexler's (1977) Freezing principle, besides being theoretically outmoded, is too strong: $\mathrm{P}, \mathrm{V}$ and all intervening material $\mathrm{X}$ must be reanalyzed into $\mathrm{V}$ so as to allow the resulting $\left[\mathrm{V}^{0} \mathrm{VXP}\right]$ to govern the trace; this freezes $\mathrm{X}$. Any word order optionality found here must therefore be base generated. This is unlikely in view of examples such as Koster's (1987: 293) (i), where a subcategorized functional PP can occur to the left of a stranded instrumental P:
}

(i) Waar ${ }_{i}$ heeft hij aan zijn dissertatie [PP $t_{i}$ mee] gewerkt?

what has he on his thesis with worked

'What did he work on his thesis with?'

Müller (1995) explains the freezing effect as follows: after movement, PPs are in an adjoined position; and extraction out of adjuncts is prohibited. However, given that instrumental PPs and many other optional PPs allow stranding, it is unclear whether the argument/adjunct status of a PP indeed determines whether stranding is allowed (Helmantel 2002: 167). In addition, the identification of the landing site of optional movement, and the base position of optional elements, under the structural heading of A' (adjoined) positions, on which the account relies, fitted well in the Barriers framework where it originates, but it is unclear whether the two position types so identified indeed form a natural class with respect to minimalist constraints on movement, however these may evolve. Finally, such an account of the Freezing effect in terms of constraints on movement will not allow us to explain the Freezing effect with weak pronouns discussed in the next section. 
scrambling, much less so for PPs. Consider, however, example (12), adapted from Broekhuis (2002).

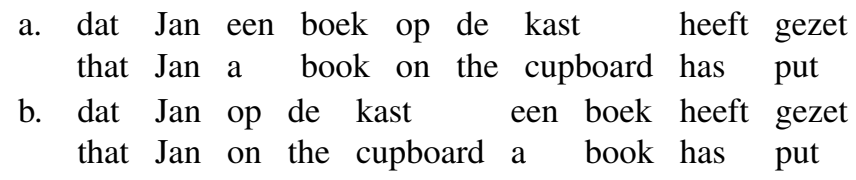

(12a) is the most 'neutral' word order: it can be produced with one pitch accent on boek 'book', giving a wide focus reading that can serve as an out-of-the-blue statement. Broekhuis (2002: 227) notes that leftward scrambling the PP in (12b) requires an "emphatic focus accent" on the complement of $\mathrm{P}$. The result is a contrastive reading. This suggests the following potential explanation of the Freezing effect (11). Consider (13):

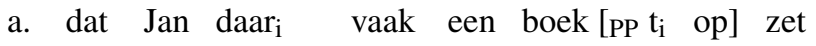

$$
\begin{aligned}
& \text { that Jan that }[+R] \text { often a book on puts } \\
& \text { 'that Jan often puts a book on that' } \\
& \text { b. * dat Jan daar } r_{i} \quad \operatorname{vaak}\left[\begin{array}{ll}
\mathrm{p}_{\mathrm{i}} & \mathrm{op}
\end{array}\right]_{\mathrm{j}} \text { een boek } \mathrm{t}_{\mathrm{j}} \text { zet } \\
& \text { that Jan that }[+R] \text { often on a book puts }
\end{aligned}
$$

In (13a), daar 'that' has undergone R-movement. In its landing-site, daar may be stressed; if it is, the same emphatic/contrastive effect is achieved as in (12b). In (13b), $\mathrm{R}$-movement of daar is preceded by PP scrambling. But the movement of the PP ends up having no information structure effect: the trace of daar has no information status by itself, and the information status of daar is fully determined by its final position, which is the same as in (13a). At this point, economy conditions of the type proposed in Reinhart $(1995,1997)$ and Neeleman and Reinhart (1998) can be invoked to rule out the derivation in (13b): it contains a superfluous optional movement operation. It seems likely to me that the incompatibility of P-stranding with optional, information driven movement operations resulting in marked word orders can be explained by this type of reasoning, in many or all instances.

However, these observations in turn suggest a related but much simpler account. If the moved PP (in marked position) must indeed have an (emphatically, contrastively, focus-) stressed complement, this explains the Freezing effect directly: P in scrambled position may not be stranded, because it requires a stressed complement, and trace cannot be stressed. I will remain agnostic here as to the primacy of the stress account or the economy account; how these are related will be left for further research; neither the pragmatic nor the prosodic properties of these constructions are well studied. I opt for the stress account of (11), because it extends naturally to the [ P x ] generalization. Further research is certainly needed to determine if Broekhuis' observation regarding (12) holds for all other relevant cases, but the data with weak pronouns below, and in the remainder of this paper, provide independent evidence that a stressable complement is indeed a prerequisite for PP scrambling. ${ }^{6}$

\footnotetext{
${ }^{6}$ See Baart (1987) for the related observation that scrambling PP prevents one integrative accent for VP. See note 9 below for related observations in English. A first modification is suggested by the observation (M. den Dikken, p.c.) that the complement of a scrambled PP can sometimes also have the continuation
} 


\subsection{PP movement and weak pronouns: the [ $\mathrm{P} \mathrm{x}]$ generalization}

The previous section proposed that optional movement of PP is allowed only if the complement of P can bear stress. Unlike a V-adjacency account of P-stranding, this Freezing-based account straightforwardly entails the following empirical predictions. Reduced, unstressed pronouns should also be disallowed in moved, stressed PPs. It follows that whenever stranding is allowed, an unstressed pronoun should also be allowed (in the absence of further constraints on the distribution of unstressed pronouns); I state this prediction as (14).

\section{(14) The [ $\mathbf{P} \mathbf{x}]$ generalization}

[ P t ] may occur only where [ $\mathrm{P}$ pro ] may occur.

(14) employs the following notational conventions. [ P t ] refers to PP with stranded $\mathrm{P}$ (relative order of $\mathrm{P}$ and $\mathrm{t}$ ignored); [ $\mathrm{P}$ pro ] refers to $\mathrm{PP}$ with unstressed, weak pronoun as complement; [ $\mathrm{P} \mathrm{x}$ ] refers to $\mathrm{PP}$ with either unstressed pronoun or trace as complement; hence the name of the generalization. Below, I will also be using [ P NP ] to refer to PP with a full, stressable complement.

The [ $\mathrm{P} \mathrm{x}$ ] generalization cannot be stated as a biconditional because, as noted in Sect. 1.1, P-stranding obeys various constraints in addition to the stress constraint (PP is not a locative/temporal adverbial, the moved element in Dutch is a $+\mathrm{R}$-pronoun, etc.), which do not apply to unstressed pronouns. However, this paper restricts attention to PPs that obey all these constraints, and allow stranding in at least some positions. For our cases, then, we do expect that $[\mathrm{P} \mathrm{t}]$ is allowed exactly where [ P pro ] is allowed. I will discuss an exception at the end of Sect. 2.

I will briefly illustrate the effect of PP-movement on the distribution of unstressed pronouns. Dutch has a strong and weak pronoun series (see Cardinaletti and Starke 1996 for general discussion). Consider first direct object pronouns (boldface indicates stress):

$$
\begin{aligned}
& \text { a. dat Jan vaak een olifant / hem / } \text { *'m heeft gezien } \\
& \text { that Jan often an elephant / him[strong] / 'm[weak] has seen } \\
& \text { b. dat Jan hem / 'm vaak heeft gezien } \\
& \text { that Jan him / 'm often has seen }
\end{aligned}
$$

In the default case (15a), a pitch accent lands on the DP immediately preceding the verb. A strong pronoun may remain in this position, with a contrastive reading, or move leftward for an unmarked reading (15b), with stress shifting to the verb (Zwart 1993 analyzes this movement as cliticization onto AGRs; Neeleman and Reinhart (1998) argue that stress shifting away from the anaphoric element is the purpose of the scrambled order). Since a weak pronoun may not bear stress, it moves obligatorily.

When the complement of V is a PP, however, the picture changes. Default stress is still on the most deeply embedded element: now the complement of P (16a). But when this element must remain unstressed, there is no movement. Instead, stress shifts away; not to P, which may usually not be stressed, but to V (16b). When the PP

rise of a topic. For me, this is not possible in (12), but it is in (16c) below. This does not affect the text account of the $[\mathrm{Px}]$ generalization but does underline the need for further research. 
does move leftward, its complement is not destressed but stressed, which blocks the weak pronoun (16c). ${ }^{7}$ This confirms my observation in the previous section: scrambled PP must have a stressed complement. ${ }^{8}$
a. dat Jan niet meer op een uitnodiging rekent that Jan no longer on an invitation counts
b. dat Jan niet meer op Marie/ hem / 'm rekent that Jan no longer on Marie / him / 'm counts
c. dat Jan op Marie/ hem/*'m niet meer rekent that Jan on Marie / him / 'm no longer counts

The pair (16c)/(2) confirms the [ $\mathrm{P} x$ ] generalization: [ $\mathrm{P} \mathrm{t}$ ] and [ $\mathrm{P}$ pro ] are allowed in exactly the same position. Further corroboration of the $[\mathrm{P} x]$ generalization is presented in the following sections. ${ }^{9}$

I want to discuss briefly two previous intimations in the literature of a generalization resembling (14). First, Ross (1967) observed that Adverbial/Temporal adjunct PPs, which disallow stranding, also tend to disallow pronominal complements:

a. * What place $\mathrm{i}_{\mathrm{i}}$ do you live at $\mathrm{t}_{\mathrm{i}}$ ?

b. * I live at the place where you met me, and dad lives at it too

Ross based his theory of P-stranding on this observation: he proposed the constraint that no NP whose head is not pronominalizable may be moved out of the environment [ $\mathrm{P}$ _ ] The constraint differs from (14), in that it generalizes over PP-types which (dis)allow [ P x ], not PP-positions. See Hornstein and Weinberg (1981: fn 11) for counterexamples to Ross' generalization.

More recently, Abels (2003: 218) has proposed the following cross-linguistic generalization: "A language allows clitic pronouns as the complements of $\mathrm{P}$ iff that language allows P-stranding [...]" His explanation is that clitics obligatorily move; so if a language blocks movement of the complement of $\mathrm{P}$ (P-stranding), the complement of $\mathrm{P}$ cannot be a clitic. This suggest an alternative approach to my intra-linguistic [ $\mathrm{P} x$ ] generalization: if Dutch weak pronouns are clitics, any account of the distribution of [ $\mathrm{P} \mathrm{t}$ ] in terms of movement conditions (e.g. the ECP), automatically

\footnotetext{
${ }^{7}$ See Gussenhoven (1992), Evers (2003), Ruys (in prep.), and references cited there for further discussion of intonation patterns in this domain.

${ }^{8}$ The situation may be different in postpositional PPs such as daar mee 'that with', where the unmarked pattern has main stress on the $\mathrm{P}$, not on its $+\mathrm{R}$ specifier. This seems to entail that the accentuation induced by scrambling is also realized on the $\mathrm{P}$, (marginally) allowing a weak pronoun specifier in (i) (M. den Dikken, p.c.):

(i) Die pen, ik denk dat Jan er mee geregeld brieven ondertekent.

that pen, I think that $\mathrm{Jan} \mathrm{it}_{[+\mathrm{R}]}$ with regularly letters undersigns

${ }^{9}$ A similar pattern has been observed with PP scrambling in English. Larson (1990) reports that Mary in (ib) bears greater stress that Bill in (ia), and a reduced pronoun in the shifted PP in (iib) is blocked accordingly (observation attributed to John Frampton, p.c.). Pesetsky (1995: 254ff) reports similar intuitions. The pattern obeys the [ P x ] generalization (cf. (6)).
}
(i) a. John talked to Mary about Bill.
b. John talked about Bill to MARY.
(ii) a. John talked to Mary about him / 'm.
b. John talked about Mary to him /*'m. 
extends to [ $\mathrm{P}$ pro ]. However, various considerations argue against this alternative. First of all, by Abels' standards, Dutch does not count as a P-stranding language, so his precise analysis cannot be applied to Dutch. This detail aside, a major problem facing Abels' position is that, in languages that allow [ $\mathrm{P}$ clitic ], the clitic does not actually appear to move out of PP; this holds for my [ P pro ] cases as well. What then of the claim that clitics obligatorily move? Abels (2001) suggests two possible solutions. His preferred option is to stipulate that clitic movement out of PP is obligatorily covert. However, as no account is provided of why this should hold, I feel this option remains too stipulative to count as a serious alternate theory. ${ }^{10}$ An alternative solution postulates that clitics move PP-internally and string-vacuously; this movement is facilitated by functional structure which also provides an escape hatch for $\mathrm{P}$-stranding, so that languages lacking this structure disallow all [ $\mathrm{P} \mathrm{x}$ ]. This alternative, however, no longer extends to the cases covered by the [ $\mathrm{P} x$ ] generalization, as optional movement of the PP as a whole should not affect the possibility of cliticmovement that remains internal to PP. Finally, an Abels-style account will run into problems in one context, to be discussed in Sect. 2, where [ P $\mathrm{t}$ ] is disallowed, but [ $\mathrm{P}$ pro ] is not. I conclude that at this juncture my stress-based account of the [ $\mathrm{P} \mathrm{x}$ ] generalization is to be preferred; establishing a possible connection between it, and Abels' generalization remains a topic that future research must address. ${ }^{11}$

Before turning to the empirical evidence, let us consider a little more closely the theoretical consequences of the [ $\mathrm{P} \mathrm{x}$ ] generalization, should we find it to be correct. I have already argued for the generalization that $\mathrm{P}$ may strand only if PP has not scrambled (Freezing); this qualifies [ $\mathrm{P} \mathrm{t}$ ] as a diagnostic for the unmarked position of PP. The [ P x ] generalization not only adds [ $\mathrm{P}$ pro ] as a diagnostic, it confirms the validity of both. First of all, we can explain the identical distribution of [ $\mathrm{P} \mathrm{t}$ ] and [ $\mathrm{P}$ pro ] by noting that both should resist stress, and that scrambling from the unmarked position requires stress; this explanation, if correct, entails freezing. In addition, the [ $\mathrm{P} x$ ] generalization can be argued to support the freezing approach directly, i.e., independently of the explanation in terms of stress. We observe that, out of all positions that scrambling makes available to a given PP, one is special in that it allows PP to be [ P x ]. There is one obvious way for a surface position to be special: by being the unmarked position (base generated, or derived through obligatory movement); this is exploited by the freezing approach. The only alternative is to assume that the "special" position which allows [ P x ] must be reached by movement out of the unmarked position; an example is Koster's (1994) hypothesis that PP must move to his Spec,PredP to allow stranding. However, if the [ P x ] generalization is correct, such an approach faces the problem of defining a common property (of traces and weak pronouns) that would force both [ $\mathrm{P} \mathrm{t}$ ] and [ $\mathrm{P}$ pro ] to move to this same position. A second problem with such an approach, independent

\footnotetext{
${ }^{10}$ Empirically, it would fail for Dutch on the overt movement of the er clitic in (5c). Also, some contexts disallow [ P t ] but not [ P pro ] (e.g., with PP as complement of P: (een kussen) voor onder je '(a pillow) for under you'vs. *voor onder $\left.t_{\mathrm{i}}\right)$.

${ }^{11}$ Despite these objections, there are indications of an intra-linguistic [ $\mathrm{P} \mathrm{x}$ ] pattern beyond the Freezing effect. Walraven (1979) observes that some prepositions never allow a weak pronominal complement. A cursory inspection suggests this matches the class of prepositions that block stranding (see Zwarts 1997), but more research is required.
} 
of the [ P x ] generalization, is that it would predict that all PPs, regardless of their grammatical function, move to the same position in the clause when they are [ $\mathrm{P} \mathrm{x} \mathrm{];}$ the truth is, as we will see below, that PPs of different types are [ P x ] in different positions (their base positions).

As a consequence, the [ $\mathrm{P} x$ ] generalization entails that we can reliably use the distribution of [ $\mathrm{P} x$ ] to determine the unmarked position of PPs in the Dutch Mittelfeld. Furthermore, I will assume, in the absence of evidence to the contrary, that PPs do not engage in Case/Agreement relations, hence undergo no obligatory movement in the Mittelfeld. Consequently, I will take one further step: that the unmarked position of a PP is in fact the position in which it is base generated. I will argue that this assumption makes exactly the right predictions. If so, the data presented here reflect directly on the base rules for the Dutch Mittelfeld, and may be used as tools in a cartographic approach to adverbial positions in this domain. Similarly, we will be able to draw conclusions as to the relative base positions of argument PPs and predicative complement PPs; the latter class (resultatives, directional PPs, predicates in copula constructions, etc.) will be discussed at length in Sects. 3 and 4.

In addition, the $[\mathrm{P} x$ ] generalization can be used to narrow down the class of successful accounts of P-stranding, and rules out many existing accounts. For instance, accounts in terms of trace licensing (ECP; Bennis' 1986 Gap Condition) or other restrictions on movement (Koster's 1987 Freezing; Hornstein and Weinberg's 1981 Reanalysis) do not extend naturally to the [ P pro ] case. This includes all V-adjacency based explanations I am aware of, as well existing Freezing-based explanations. The [ P x ] generalization argues in particular against accounts (Sturm and Kerstens 1978; Hoekstra 1979; Neeleman 1994; Zwart 1993) that attribute the position of stranded P in some examples to (rightward) movement of $\mathrm{P}$ - it is unlikely that a similar movement could be motivated for [ $\mathrm{P}$ pro ] in such examples.

\section{The [ P x ] generalization and the Dutch Mittelfeld}

This section reviews stranding and unstressed pronoun options with a small sample of Dutch PP classes that allow stranding. The purpose of this review is twofold: to demonstrate that the [ $\mathrm{Px}$ ] generalization holds, and to draw preliminary conclusions as to the unmarked positions of these PP types in the Dutch Mittelfeld.

Consider first argument PPs with a "functional" preposition (in the terminology of Broekhuis 2002). (18) below expands on the relevant examples in (2), (3) and (16). The unscrambled order in (18a), (18b) allows both weak pronouns and P-stranding. The scrambled order in (18c), (18d) disallows both weak pronouns and P-stranding.
a. dat Jan niet op ' $\mathrm{m} / \mathrm{d}$ 'r/ze/je/me
had gerekend
that Jan not on him/her/them/you/me had counted
b. de beslissing waar ${ }_{i}$ Jan niet [PP $t_{i}$ op] had gerekend the decision which $[+\mathrm{R}]$ Jan not on had counted
c. * dat Jan op ' $\mathrm{m} / \mathrm{d}$ 'r/ze/je/me niet had gerekend that Jan on him/her/them/you/me not had counted
d. * de beslissing waar $_{i} \quad J_{\text {Jan }}\left[\begin{array}{ll}\mathrm{PP}_{\mathrm{i}} & \mathrm{op}\end{array}\right]_{\mathrm{j}}$ niet $\mathrm{t}_{\mathrm{j}}$ had gerekend the decision which $_{[+\mathrm{R}]}$ Jan on not had counted


The facts in (18) thus support the [ $\mathrm{P} \mathrm{x}$ ] generalization: [ $\mathrm{P} \mathrm{t}$ ] is allowed just where [ $\mathrm{P}$ pro ] is allowed, namely in the immediately preverbal position.

Consider next instrumental PP adverbials. ${ }^{12}$ I will begin by determining their default position relative to the direct object.

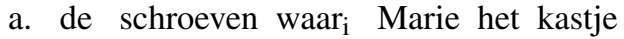
$\left[t_{i}\right.$ mee] repareerde the screws which Marie the cupboard with repaired
b. dat Marie het kastje met ze repareerde (, met die schroeven) that Marie the cupboard with them repaired (, with those screws)
c. ?? de schroeven waar $_{i}$ Marie $\left[\mathrm{t}_{\mathrm{i}}\right.$ mee] het kastje repareerde the screws which Marie with the cupboard repaired
d. ?? dat Marie met ze het kastje repareerde (, met die schroeven) that Marie with them the cupboard repaired (, with those screws)

These examples confirm the [ $\mathrm{P} x$ ] generalization, and indicate that the unmarked position of instrumental PPs is to the right of the direct object, between the object and the verb.

How is this unmarked order derived? The natural assumption is that the object DP het kastje 'the cupboard' is generated in a theta-position adjacent to the verb. Examples like (19a) therefore caused Hoekstra (1979) to assume that P moves rightward across DP (see the discussion of (9a) above). As explained before, such a P-movement analysis (also Sturm and Kerstens 1978; Neeleman 1994; Zwart 1993) might explain $\mathrm{V}$-adjacency of stranded P in (19a), but not V-adjacency of [ P pro ] in (19b). [ P pro ] should not be able to undergo the head-movement postulated for stranded P; and triggers that have been proposed for P-movement, e.g. in terms of licensing the trace in [ $\mathrm{P} \mathrm{t}$ ], do not extend to [ $\mathrm{P}$ pro ]. Rejecting a rightward P-movement analysis of Pstranding, Koster (1987: 181ff) concluded from the contrast exemplified by (19a) vs (19c) (reported earlier in Koster 1978: 104), albeit with some understandable hesitation, that the natural assumption might be wrong: the underlying order might be with het kastje 'the cupboard' separated from the verb by the instrumental PP.

Recent work has, of course, provided a more natural analysis. The object is generated in a $\mathrm{V}$-adjacent position, and reaches its unmarked position by obligatory leftward movement across the PP. This movement must be obligatory; otherwise, the $\mathrm{PP}-\mathrm{OB}$ order could be derived by leaving OB in situ, without moving PP, hence allowing [ $\mathrm{P} \mathrm{x}$ ]. As it is, for PP to appear to the left of the moved OB it will have to move in turn, blocking [ $\mathrm{P} \mathrm{x}$ ] in this position. Obligatory movement of object DPs in Dutch can naturally be analyzed as movement to Spec,AGRo for Case, as proposed originally in van den Wyngaerd (1989). It can be shown independently that the DPmovement which generates the OB - PP order in (19) is indeed for Case/Agreement and is not "scrambling" (i.e., optional DP-movement associated with specificity, etc):

\footnotetext{
${ }^{12}$ Example construction is complicated here by the fact that only thuman unstressed pronouns are allowed to the right of P; $P$ het 'P it' is blocked by er $P$ 'there P' with clitic er; see Van Riemsdijk (1978) and Broekhuis (2002); but +human pronouns are awkward as instrumentals; I use the plural \pm human pronoun $z e$ 'them', for which the constraint is somewhat relaxed, although not for all speakers. In some examples, I use a right-dislocated element associated with the PP; this both triggers the choice for a reduced pronoun, and makes it possible to force the instrumental reading (as opposed to a comitative one) for the with-PP.
} 
DPs that generally resist scrambling, such as unstressed wat (non-specific 'something') nonetheless occur to the left of $\mathrm{PP}_{\text {Instr }}$.
a. dat Marie <*wat> vaak <wat $>$ repareerde
that Marie <smthing $>$ often $<$ smthing $>$ repaired
a. waar $\mathrm{w}_{\mathrm{i}}$ Marie <wat $>\left[\mathrm{t}_{\mathrm{i}}\right.$ mee $]<*$ wat $>$ repareerde which $_{\mathrm{i}}$ Marie <smthing $>$ with $<$ smthing $>$ repaired
b. dat Marie <wat> met ze <*wat> repareerde that Marie <smthing $>$ with them <smthing $>$ repaired
c. dat Marie wat met die schroeven repareerde that Marie smthing with those screws repaired

(20) shows that wat does not scramble; (21) shows that it occurs to the left of PP nonetheless; this order must therefore result from obligatory (Case-related) movement. The crucial fact is that wat can appear to the left of a full PP: [ P pro ] in (21b), and [ P NP ] in (21c). As this order can be due neither to rightward P-movement, nor to leftward optional scrambling of wat, these examples are independent evidence that $\mathrm{OB}-\mathrm{PP}_{\text {Instr }}-\mathrm{V}$ is indeed the unmarked order. ${ }^{13}$ This analysis removes the apparent evidence for $\mathrm{V}$-adjacency from (9a).

Consider next the behavior of PP arguments. If, as I assume, the default position of the DP object to the left of the adverbial PP is due to Case movement of the DP, then the default order should be reversed when the object is itself a PP, which does not move for Case. The following examples involve an argument PP co-occurring with an instrumental PP. Consider first the order $\mathrm{PP}_{\text {Instr }}-\mathrm{PP}_{\mathrm{Arg}}-\mathrm{V}$ (I will use $\mathrm{PP}_{\text {Arg }}$ to stand for PP with a "functional" P). ${ }^{14}$
a. de verrekijker waar $_{i}$
b. dat
Jan $\left[\right.$ mee $\left.t_{i}\right]$
Jan met ze
naar Marie heeft gekeken naar Marie heeft gekeken
\{the binoculars which $_{\mathrm{i}} /$ that $\}$ Jan with $\left\{\mathrm{t}_{\mathrm{i}} / \mathrm{them}\right\}$ at Marie has looked
c. de toren waar $_{i}$ Jan met de verrekijker [naar $t_{i}$ ] keek
d. dat Jan met de verrekijker naar d'r keek
\{the tower which $\mathrm{i} /$ that $\}$ Jan with the binoculars at $\left\{\mathrm{t}_{\mathrm{i}} /\right.$ her $\}$ looked

(22) shows that on this order, both the left-hand PP in (22a), (22b) and the right-hand $\mathrm{PP}$ in (22c), (22d) may be [ P x ]: either [ P t ], or [ P pro ]. In fact, on this order, both PPs may take the $[\mathrm{P} x$ ] form:
a. de verrekijker waar Jan $_{\mathrm{t}_{\mathrm{i}}}$ mee] naar je keek the binoculars which Jan with at you looked
b. de toren waar $i_{i}$ Jan met ze $\left[t_{i}\right.$ naar $]$ heeft gekeken the tower which Jan with them at has looked

\footnotetext{
${ }^{13}$ Koopman and Sportiche (1991) also argued for Case movement using a scrambling-resistant DP, but on the basis of a P-stranding structure like (21a); this however is the one case that does not unequivocally support movement of wat, as it might result from P-movement, as discussed above. In German, elements like wat occurring as complements of $\mathrm{P}$ (sometimes) block PP-scrambling, creating a test for unmarked PP-positions similar to my [ P pro ] test; see Frey and Pittner (1998).

${ }^{14}$ Here and below, I will often indicate the trace to the right of the stranded postposition, for ease of glossing.
} 

c. dat Jan met ze naar je heeft gekeken
that Jan with them at you has looked
d. ? de toren waar Jan er $_{\mathrm{i}}$ vaak $\left[\mathrm{t}_{\mathrm{i}}\right.$ mee $]\left[\mathrm{t}_{\mathrm{j}}\right.$ naar $]$ heeft gekeken the tower which Jan $\mathrm{it}_{[+\mathrm{R}]}$ often with at has looked

On my account, this means that $\mathrm{PP}_{\text {Instr }}-\mathrm{PP}_{\mathrm{Arg}}$ is the unmarked order. This, the opposite of the $\mathrm{OB}-\mathrm{PP}_{\text {Instr }}$ order, confirms the assumption that PPs undergo no obligatory checking movement, making the base position the unmarked one. Note, that the examples of stranded $\mathrm{P}_{\mathrm{Instr}}$ are counterexamples to the supposed generalization that stranded P must be V-adjacent. ${ }^{15}$

What do we expect for the opposite order? Assuming that rightward (downward) movement of $\mathrm{PP}$ is blocked, the inverse order $\mathrm{PP}_{\mathrm{Arg}}-\mathrm{PP}_{\text {Instr }}$ must be derived through leftward movement of $\mathrm{PP}_{\mathrm{Arg}}$. Hence, we expect that $\mathrm{PP}_{\text {Instr }}$ can still be $[\mathrm{P} \mathrm{x}]$, but $\mathrm{PP}_{\text {Arg }}$ cannot, and these predictions are confirmed. ${ }^{16}$
a. de verrekijker waari
Jan [pp naar Marie $]_{j}\left[p p\right.$ mee $\left.t_{i}\right] t_{j}$
heeft gekeken
b. dat Jan [PP naar Marie]
heeft gekeken
\{the binoculars which $/$ that $\}$ Jan at Marie with $\left\{\mathrm{t}_{\mathrm{i}} /\right.$ them $\}$ has looked
c. * de vrouw waar $i_{i} \quad$ Jan $\left[p P \text { naar } t_{i}\right]_{j}$ met de verrekijker $t_{j}$ heeft gekeken
d. * dat Jan [PP naar je] $]_{j}$ met de verrekijker $t_{j}$ heeft gekeken \{the woman which $/$ that $\}$ Jan at $\left\{\mathrm{t}_{\mathrm{i}} / \mathrm{you}\right\}$ with the binoculars has looked

The net result is, of course, that $[\mathrm{P} \mathrm{t}]$ in these cases is $\mathrm{V}$-adjacent, and that non$\mathrm{V}$-adjacent [ P t ] in (24c) is blocked. But a V-adjacency account of P-stranding is already thoroughly discredited. First, because (22) and (23) provide counterexamples, in addition to those already identified earlier (see the discussion of (10) above; more counterexamples are to follow). Second, because V-adjacency is also observed in (24) for [ P pro ], which compromises existing theoretical accounts of the supposed $\mathrm{V}$-adjacency requirement.

Combining the observations so far, I have identified the following default order in the Dutch Mittelfeld: ${ }^{17}$

\footnotetext{
${ }^{15}$ Broekhuis (2002: 289) observes that a stranded P may intervene between $\mathrm{V}$ and a second stranded $\mathrm{P}$, violating adjacency, and that the relative order of two stranded P's reflects the unmarked order of the PPs.

${ }^{16}$ See, e.g., Hoekstra (1979: (18)), and also (i) in note 5 for further well-formed examples like (24a). One reviewer and one informant reject such examples, but for reasons orthogonal to our concerns: these speakers also reject the scrambled order if no P-stranding takes place, citing special intonation requirements. Such requirements of course are exactly what explain the contrast in (24) under my analysis; under appropriate prosodic conditions, my informant does accept (24a).

${ }^{17}$ I will not further differentiate the $\mathrm{OB}$ and Neg positions here; I presume that further work along these lines would result in a default order $\mathrm{OB}_{\text {definite }}-\mathrm{Neg}-\mathrm{OB}_{\text {indefinite }}$ - etc. (see Hinterhölzl 2000), but such details lie outside the scope of the present paper. The default order identified here and below conforms closely to Van Riemsdijk's (1978) rewrite rule for VP.
} 
(25)
OB PP $P_{\text {Instr }} \mathrm{PP}_{\text {Arg }} \mathrm{V}$ NEG

I will discuss three more classes of PP types which further demonstrate the correctness of the [ $\mathrm{P} x$ ] generalization, and the applicability and limitations of my approach to probing the default PP order. Consider first Dative PPs.
a. de tang waari
Jan dat boek mee $t_{i}$
aan Piet heeft overhandigd
b. ? dat
Jan dat boek met ze aan Piet heeft overhandigd
\{the tongs which $/$ that $\}$ Jan that book with $\left\{\mathrm{t}_{\mathrm{i}} /\right.$ them $\}$ to Piet has handed
a. * de man waari
Jan dat boek [PP aan $\left.t_{i}\right]_{j}$ met een tang $t_{j}$ heeft overhandigd
b. * dat Jan dat boek [PP aan ' $m]_{j}$ met een tang $t_{j}$ heeft overhandigd \{the man which $\mathrm{i}_{\mathrm{i}} /$ that $\}$ Jan that book to $\left\{\mathrm{t}_{\mathrm{i}} /{ }^{\prime} \mathrm{m}\right\}$ with a tongs has handed

From (26) it follows that the base position of $\mathrm{PP}_{\text {Instr }}$ should be to the left of $\mathrm{PP}_{\mathrm{Dat}}{ }^{18}$ Hence, on the reverse order, $\mathrm{PP}_{\mathrm{Dat}}$ should be "frozen" and disallow [ P X ]. (27) shows that this is correct. Of course, moving $\mathrm{PP}_{\mathrm{Dat}}$ to the left of $\mathrm{OB}$ also blocks $[\mathrm{P} \mathrm{x}]$ :
a. * de man waari
Jan $\left[P P \text { aan } t_{i}\right]_{j}$ een boek $t_{j}$ heeft overhandigd
b. * dat
Jan [PP aan 'm] $]_{j}$ een boek $t_{j}$ heeft overhandigd
\{the man which ${ }_{\mathrm{i}} /$ that $\}$ Jan to $\left\{\mathrm{t}_{\mathrm{i}} /{ }^{\prime} \mathrm{m}\right\}$ a book has handed

The same pattern can be found e.g. with directional argument PPs. The order $\mathrm{PP}_{\text {Instr }}-\mathrm{PP}_{\text {Dir }}$, with $\mathrm{PP}_{\text {Dir }}$ argumental, allows [ $\mathrm{P} \mathrm{x}$ ] in either PP:

(29) a. de hamer waar ${ }_{i}$ hij $\left[\right.$ mee $\left._{i}\right]$ op de tafel heeft getimmerd the hammer which $\mathrm{i}_{\mathrm{i}}$ he with on the table has hammered

b. dat hij met ze op de tafel heeft getimmerd (, met die hamers) that he with them on the table has hammered (, with those hammers)

c. de tafel waar $r_{i}$ hij met de hamer [op $t_{i}$ ] heeft getimmerd the table which ${ }_{i}$ he with the hammer on has hammered

d. dat hij met de hamer op ze heeft getimmerd (, op die tafels) that he with the hammer on them has hammered (, on those tables)

whereas the opposite order $\mathrm{PP}_{\mathrm{Dir}}-\mathrm{PP}_{\text {Instr }}$ allows [ $\mathrm{P} \mathrm{x}$ ] for the right-hand PP only:

(30) a. de hamer waar ${ }_{i}$ hij op de tafel [mee $t_{i}$ ] heeft getimmerd the hammer which he on the table with has hammered

b. dat hij op de tafel met ze heeft getimmerd (, met die hamers) that he on the table with them has hammered (, with those hammers)

c. * de tafel waar ${ }_{i}$ hij [op $\left.t_{i}\right]$ met de hamer heeft getimmerd the table which he on with the hammer has hammered

d. * dat hij op ze met de hamer heeft getimmerd (, op die tafels) that he on them with the hammer has hammered (, on those tables)

This extends the default order to:

\footnotetext{
${ }^{18}$ Dative PPs are listed by Bennis and Hoekstra (1984) and Bennis (1986) among the elements exceptionally allowed between stranded $\mathrm{P}$ and $\mathrm{V}$.
} 


$$
\begin{array}{lll}
\text { OB } & \mathrm{PP}_{\text {Instr }} & \mathrm{PP}_{\text {Arg }} \\
\text { NEG } & & \mathrm{PP}_{\text {Dat }} \\
& & \mathrm{PP}_{\text {Dir }}
\end{array}
$$

$\mathrm{PP}_{\text {Dat }}, \mathrm{PP}_{\text {Dir }}$ and $\mathrm{PP}_{\text {Arg }}$ do not co-occur, so no relative order can be established.

So far, I have considered cases where the default ordering of PPs is fixed. Benefactive PPs and passive by-phrases appear to present a case of optionality. Consider (32) and (33):

(32) a. de experts waar ${ }_{i}$ het huis [door $\left.t_{i}\right]$ voor een cliënt zal worden ingericht the experts which the house by for a client will be decorated

b. dat het huis door ze voor een cliënt zal worden ingericht that the house by them for a client will be decorated

(33) a. de cliënten waar ${ }_{i}$ het huis [voor $t_{i}$ ] door een expert zal worden ingericht the clients which the house for by an expert will be decorated

b. dat het huis voor ze door een expert zal worden ingericht that the house for them by an expert will be decorated

If the unmarked relative order of these PPs were fixed, there should be one order (the derived one) in which the moved element (i.e., the leftmost one) could not be [ P x ]. While intuitions are fairly subtle, I detect no contrast between (32) and (33), and I tentatively conclude that these semi-arguments may be generated in arbitrary order. If so, an approach to the base distribution of such elements with dedicated functional projections in a fixed order, as proposed for adverbial PPs in Cinque (2002), would not work here. See Schweikert (2005) for an inventory of further tests that might be employed to decide the issue.

We have now arrived at the following base order (I tentatively place by-phrase and Benefactive to the right of $\mathrm{PP}_{\text {Instr }}$; intuitions are subtle, and investigating these cases here would provide no further insight; on the basis of a constituency test, Cinque 2002 places Benefactives higher than Instrumentals for Italian; Schweikert 2005 does too).

$$
\begin{array}{llll}
\text { OB } & \mathrm{PP}_{\text {Instr }} & \mathrm{PP}_{\text {by }} & \mathrm{PP}_{\text {Arg }} \\
\text { NEG } & & \mathrm{PP}_{\text {Ben }} & \mathrm{PP}_{\text {Dat }} \\
& & & \mathrm{PP}_{\text {Dir }}
\end{array}
$$

There is a final set of examples that deserves attention at this point:
a. de hijskraan waar ${ }_{i}$ het boek mee door Jan aan Marie werd gegeven the crane which the book with by Jan to Marie was given

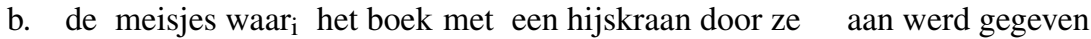 the girls which the book with a crane by them to was given
a. * de meisjes waar
het boek aan $\mathrm{t}_{\mathrm{i}}$
door Jan werd gegeven
b. * dat
het boek aan ze
door Jan werd gegeven
$\left\{\right.$ the girls which $\mathrm{i}_{\mathrm{i}}$ that $\}$ the book to $\left\{\mathrm{t}_{\mathrm{i}} /\right.$ them $\}$ by Jan was given

The examples involve three PPs: instrumental PP, passive by-phrase, and dative PP, which naturally occur in that order (see (35a)). Now observe in (36) that the dative PP may not be $[\mathrm{Px}]$ when it is to the left of the by-phrase. This is what we expect, given that (36) shows $\mathrm{PP}_{\mathrm{Dat}}$ in a derived position. However, some theories (Bennis 1986; Neeleman 1994) assume that a P-adjacency requirement holds for [ P t ], and deal with 
apparent exceptions, with $\mathrm{X}$ intervening between [ $\mathrm{P} \mathrm{t}$ ] and $\mathrm{V}$, by assuming that in those cases, $\mathrm{X}$ is "incorporated" into V or forms a "complex predicate" with V. Such theories fail on (35)/(36): from the well-formedness of (35a) and similar cases one would have to conclude that the $b y$-phrase can be part of such a complex predicate; but then (36) should be allowed as well.

In this section, I have considered one type of movement of PP (leftward scrambling) and found that the [ $\mathrm{Px}$ ] generalization holds. Before turning to PP interactions in the rightmost part of the Dutch Mittelfeld, let us look briefly at one other type of movement, rightward extraposition of PP ("PP-over-V"), which presents an exception to the $[\mathrm{P} x$ ] generalization. In the cases I have considered so far, PP movement requires stressing the complement of $\mathrm{P}$. This does not, however, appear to be the case with PP-extraposition: the extraposed PP may be informationally "backgrounded", and destressed.

Q Is Marie Jan al snel gaan opzoeken?

Is Marie Jan already soon gone seek

'Did Marie go and look up Jan soon?'

(38) a. \# Nee, hij heeft op Marie lang moeten wachten.

no, he has for Marie long must wait

'No, he had to wait for Marie long.'

b. Nee, hij heeft lang op Marie moeten wachten.

no, he has long for Marie must wait

c. Nee, hij heeft lang moeten wachten op Marie.

no, he has long must wait for Marie

d. Nee, hij heeft lang moeten wachten op d'r.

no, he has long must wait for her

As a reply to (37), the scrambled order in (38a) is fairly unnatural, as it results in stress on discourse-familiar Marie. The orders in (38b) and (38c) are both acceptable: in these cases, only the verb wachten 'wait' bears a pitch accent, followed in (38c) by a low tone stretching to the end of the extraposed PP. Given these observations, one expects that [ $\mathrm{P}$ pro ] may also undergo PP-over-V. This is borne out by the acceptability of (38d).

The $[\mathrm{P} \mathrm{x}$ ] generalization, if stated as a biconditional, would now predict that $[\mathrm{Pt}$ ] should also be allowed in extraposed position; a false prediction, as is well known:

$$
\begin{array}{lllllll}
* \text { de } & \text { beslissing } & \text { waar }_{i} & \text { Jan lang } t_{j} & \text { heeft moeten } & \text { wachten }\left[\mathrm{pP}_{\mathrm{i}}\right. & \text { op }]_{\mathrm{j}} \\
\text { the } & \text { decision } \text { which }_{\mathrm{i}} & \text { Jan long } & \text { has must } & \text { wait } & \text { for }
\end{array}
$$

(39) must violate some additional constraint on wh-movement that is not relevant in (38d), where no wh-movement takes place. As explained in Sect. 1.1, it is not the purpose of this paper to propose a general theory of conditions on P-stranding. Nonetheless, I want to suggest two possible solutions that may be pursued.

One option is to derive (39) from the economy account of the [ P x ] generalization discussed in Sect. 1.1. PP-over-V allows an unstressed complement of $\mathrm{P}$ when it functions to background and destress the PP, as in (38d). However, subsequent movement of the complement of $\mathrm{P}$ will undo this backgrounding effect, as the information 
status of the complement will be determined by its ultimate landing site. Hence, PPover-V in (39) is blocked by economy considerations as proposed in Reinhart (1995) and subsequent work. ${ }^{19}$

An alternative approach is to assume that PP-over-V is a "stylistic" rule, that is, takes place after spell-out in the PF component. ${ }^{20} \mathrm{~A}$ possible implementation is along the lines of Chomsky's (2001) treatment of TH/EX: both the source and target of $\mathrm{TH} / \mathrm{EX}$ are inaccessible to wh-movement; if PP-extraposition is a type of TH/EX, the facts follow. ${ }^{21}$ This alternative presupposes, however, that PP-over-V involves movement, no longer a common assumption (see Barbiers 1995 and references cited there).

While a full account of (39) must await further research, one can argue nonetheless that the divergence of [ $\mathrm{P} \mathrm{t}$ ] and [ P pro ] in the context of PP-over-V supports the approach defended here, rather than undermining it, for the following reason. The fact that [ $\mathrm{P}$ pro ] is allowed in extraposed position, is in accordance with my stress/information structure account of its distribution and that of [ $\mathrm{Pt}$ ]. An approach to $\mathrm{P}$-stranding that requires stranded $\mathrm{P}$ to be adjacent to $\mathrm{V}$, or to move to a position adjacent to $\mathrm{V}$ or $\mathrm{F}$ in the extended projection of $\mathrm{V}$ (such as Neeleman 1994 and Zwart 1993, discussed further in Sect. 3) might attempt to account for the [ P x ] generalization by claiming that $\mathrm{P}+$ pro must undergo a similar (clitic-like) movement. This approach fails, however, in the face of (38d): extraposed [ P pro ] does not behave like a proclitic, and behaves differently than $[\mathrm{P} \mathrm{t}]$. For the same reason, the extraposition facts argue against a clitic-movement account of the [ P x ] generalization (cf. Abels 2003; see Sect. 1.2 above): if the pronoun covertly moves out of [ P pro ], reducing it to [ P t ], then [ P pro ] in (38d) should be blocked by whatever blocks [ P t ] in (39).

In this section, I have demonstrated the validity of the [ $\mathrm{P} x$ ] generalization (modulo the above remarks on PP-extraposition). Stranded P may occur only where a weak pronominal $\mathrm{P}$ complement may appear, i.e., in positions that do not require the complement of $\mathrm{P}$ to be stressed. This explains the prohibition against scrambling stranded $\mathrm{P}$. The analysis of P-stranding in terms of $\mathrm{V}$-adjacency has proven inadequate: we have seen virtually any type of PP intervening between stranded $\mathrm{P}$ and $\mathrm{V}$. I have used the [ $\mathrm{P} \mathrm{t}$ ] and [ $\mathrm{P}$ pro ] examples to test for the base-generated, unmarked order of the Dutch Mittelfeld, with more fine-grained results than achieved by other tests. So far, the unmarked orders we have arrived at in (34) are unremarkable, and conform closely to what previous research has led us to expect; indeed, we would

\footnotetext{
${ }^{19}$ This analysis does not presuppose that extraposition involves movement; in a VP-intraposition approach to PP-over-V (Barbiers 1995), overtness of intraposition could be made subject to the relevant economy constraint.

${ }^{20}$ See Guéron (1980) and references cited there for discussion of this view in the case of PP-extraposition from NP; see also Fox and Nissenbaum (1999) for an argument that PP-extraposition from NP is not phonological. Dutch PP-over-V does not appear to feed into scope relations and NPI licensing. Note that, in a Multiple Spell-Out model as proposed in Chomsky (2001), PP-over-V may be a PF-operation and still feed into VP-fronting. See Barbiers (1995) for a different view.

${ }^{21}$ That the ban on stranding after PP-over-V should receive a different explanation than the ban on stranding after PP-scrambling receives support from the fact that the two contexts show diverging behavior cross-linguistically: PP-over-V allows stranding in German, while PP-scrambling does not (see Müller 1997). I must leave the explanation for the German PP-over-V facts for further research.
} 
hesitate to trust the [ $\mathrm{P} x$ ] test if its results on the simple structures investigated here had deviated too far from our expectations. One interesting point is that the analysis confirms Koster's (1987) insight that the unmarked order is OB - PP - V for Instrumental and other adverbial PPs; assuming underlying V-adjacency of $\mathrm{OB}$, this indicates that objects undergo obligatory (Case-driven) movement. The issue is taken up again in the following sections, which investigate the position of PPs relative to resultatives and other predicative complements.

\section{AP / NP Small Clauses}

The remainder of this paper focuses on a more contentious issue: the position of predicative complements, a category that includes resultatives, consider-type complements, and predicates in copula constructions. For convenience, I will refer to these expressions as Small Clause predicates; but the reader will find that the conclusions are independent of the SC analysis. There are several reasons for discussing these constructions here. Word order phenomena in predicative complements provide prima facie evidence in favor of a $\mathrm{P}$-movement ( $\mathrm{V}$-adjacency) analysis of $\mathrm{P}$-stranding; I will argue that the Freezing account is nonetheless to be preferred. Also, the analysis I will propose supports the conclusions of the foregoing sections, by showing that predicates (like arguments) undergo obligatory movement in the Mittelfeld, with PP predicates (like PP arguments) exempt from such movement. To summarize in advance, we will find that the base, unmarked position of adverbial (instrumental, etc.) PPs is to the right of AP/NP SC-predicates, but to the left of PP predicates, as indicated in (40):

$$
\left(\mathrm{AP}_{\text {Pred }}\right) \quad \mathrm{PP}_{\mathrm{Adv}}\left(\mathrm{PP}_{\text {Pred }}\right) \mathrm{V}
$$

We will see, however, that the unmarked order (40) is not easily established, as the AP predicate may also occur more to the right, incorporated into the verb, and the adverbial PP may be forced to move leftward for prosodic reasons.

The present section discusses the position of adverbial PPs relative to Small Clause predicates with an adjectival or nominal head; the case of SC predicates which are themselves PPs is discussed in the next section. The basic facts in this domain, many familiar from the literature, can be summarized as follows. An adverbial PP with a full NP complement, [ P NP ], must precede the AP SC predicate (Hoekstra 1979; Zwart 1993; Neeleman 1994, and references cited there):

$$
\begin{aligned}
& \text { a. * dat Jan Marie (heel) bang met zijn verhaaltjes maakt } \\
& \text { that Jan Marie (very) afraid with his stories makes } \\
& \text { b. dat Jan Marie met zijn verhaaltjes (heel) bang maakt } \\
& \text { that Jan Marie with his stories (very) afraid makes }
\end{aligned}
$$

A stranded P, on the other hand, must usually be V-adjacent, following an AP SCpredicate:

a. * waar Jan Marie [PP mee $\left.\mathrm{t}_{\mathrm{i}}\right]$
$\begin{aligned} & \text { which Jeel bang makt } \\ & \text { very afraid makes }\end{aligned}$
b. waar ${ }_{i}$ Jan Marie heel bang [PP mee $\left.\mathrm{t}_{\mathrm{i}}\right]$ makt
which Jan Marie very afraid with makes


Such contrasts led Hoekstra (1979) to assume rightward movement of stranded $\mathrm{P}$ across the SC predicate (see Sect. 1.1), an analysis I shall be attempting to disprove.

Non-branching AP SC-predicates, however, behave exceptionally in that a stranded $\mathrm{P}$ may sometimes occur either to the left or to the right of the adjectival head:

a. waar ${ }_{i}$ Jan Marie [pP mee $t_{i}$ ] bang heeft gemaakt which Jan Marie with afraid has made 'which Jan has made Marie afraid with'

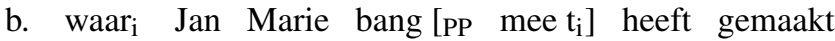
which Jan Marie afraid with has made

Before explaining my analysis, let me briefly discuss some existing, related analyses. Koster's $(1994,1999,2000)$ discussion states that the AP predicate moves into the Spec of a designated PredP functional projection, and PP-adverbials may do so as well; it is only in Spec,PredP that P may be stranded. The analysis entails no constraint, however, on the ordering among elements in Spec,PredP, so that none of the ordering restrictions I shall discuss are derived.

Both Neeleman (1994) and Zwart (1993) assume that the unmarked position of AP is V-adjacent. This explains why [ P NP ] does not intervene between AP and V (see (41)). The AP [ P t ] V order in $(42 b) /(43 b)$ is then attributed to movement of P. It cannot be attributed to movement of AP away from its unmarked $\mathrm{V}$-adjacent position, as this would upset the explanation for (41), and because SC-predicate scrambling is generally degraded:

(44) dat Jan <*bang> Marie <*bang> vaak <bang> maakt that Jan <afraid > Marie <afraid > often <afraid > makes

Technically, for Neeleman (1994) AP and V form a (syntactically generated) complex predicate. Stranded $\mathrm{P}$ must incorporate into the predicate; it may either incorporate into the full complex predicate, giving the P A V order of (43a), or move rightward and incorporate into its V head, giving the A P V order of $(42 b) /(43 b)$. The P AP $\mathrm{V}$ order in (42a) is ruled out by an additional filter that blocks P-incorporation into a complex predicate with a branching left-hand AP member, forcing the rightward $\mathrm{P}$-movement and incorporation into $\mathrm{V}$.

For Zwart, who assumes the LCA (Kayne 1994), the underlying order is (45a).
a. $\quad\left[\right.$ Pred $^{\prime}$ Pred $^{0} \quad[$ IVPP
b. [PredP AP ${ }_{\text {Pred }^{\prime}} \mathrm{V}+$ Pred $^{0} \quad[\mathrm{VP} P \mathrm{PP}$
[VP V [sC DP AP ]]]]
$\left.\left.\left.\left.\left[\mathrm{VP}_{\mathrm{V}} \mathrm{t}_{\mathrm{SC}} \mathrm{t}_{\mathrm{DP}} \mathrm{t}_{\mathrm{AP}}\right]\right]\right]\right]\right]$
c. $\left[\right.$ PredP AP $\left[\right.$ Pred $^{\prime} \mathrm{P}+\mathrm{V}+\mathrm{Pred}^{0}$
[VP [PP $\left.\mathrm{t}_{\mathrm{wh}} \mathrm{t}_{\mathrm{P}}\right]$
$\left.\left.\left.\left[\mathrm{vP}_{\mathrm{V}}\left[\mathrm{sC} \mathrm{t}_{\mathrm{DP}} \mathrm{t}_{\mathrm{AP}}\right]\right]\right]\right]\right]$

Starting from (45a), AP must move into the spec of PredP, with V moving to $\operatorname{Pred}^{0}$, resulting in (45b). P in (42b)/(43b) adjoins to $\mathrm{V}$ in $\mathrm{Pred}^{0}$, so as to render PP transparent for extraction; see (45c). ${ }^{22}$ The P A V order of (43a) is due to P-adjunction to a higher $\mathrm{F}^{0}$; there is no account for why this option is limited to non-branching AP. It

\footnotetext{
${ }^{22}$ When P is not stranded, PP can remain in situ, yielding the extraposed, "PP-over-V" order, or scramble leftward.
} 
is clear that neither Neeleman (1994) nor Zwart (1993) will be able to explain the codistribution of [ $\mathrm{Pt}$ ] and [ $\mathrm{P}$ pro ], if we find that the [ $\mathrm{P} \mathrm{x}$ ] generalization continues to hold, since [ $\mathrm{P}$ pro ] cannot undergo head-movement.

The analysis closest to the one I will propose is Zwart (1997). As in Zwart (1993), the underlying order is (46a), and the SC predicate moves to Spec,PredP, yielding (46b).
a. $\quad\left[\right.$ Pred $^{\prime}$ Pred $^{0} \quad[\mathrm{VP} P \mathrm{PP}$
[VP V [sc DP AP ]]]]
b. $\quad\left[\right.$ PredP AP ${ }_{\left[\text {Pred }^{\prime}\right.}$ Pred $^{0} \quad[\mathrm{VP} P P$
$\left.\left.\left.\left[\mathrm{VP} \mathrm{V}\left[\mathrm{sC} \mathrm{t}_{\mathrm{DP}} \mathrm{t}_{\mathrm{AP}}\right]\right]\right]\right]\right]$

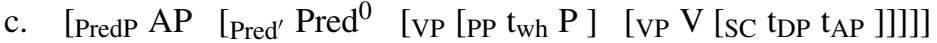

However, $\mathrm{V}$ does not move to $\operatorname{Pred}^{0}$, and neither does $\mathrm{P}$; this yields the $\mathrm{AP}-[\mathrm{P} \mathrm{t}]-\mathrm{V}$ order, as shown in (46c) (see below for why the full [ P NP ] may not remain between AP and V). ${ }^{23}$ The $[\mathrm{Pt}]-\mathrm{A}-\mathrm{V}$ order of (43a) is derived by base-generating PP in a higher position; as in Zwart (1993), there is no account for why this option is limited to non-branching AP. My analysis will be similar to (46), the most significant difference being that I generate SC to the left of $\mathrm{V}$, violating the LCA; furthermore, I propose a different analysis for the [ $\mathrm{P} t \mathrm{t}]-\mathrm{A}-\mathrm{V}$ order, and for PP SC-predicates; I will point out these distinctions as the discussion proceeds.

In this section, I will propose an analysis and provide evidence for it by using [ $\mathrm{P} x$ ] to test for the base position of the adverbial PP. I will first concentrate, in Sect. 3.1, on structures with a branching AP (or nominal) predicate, which only allow the stranded P to their right; I will return to the optionality found with non-branching AP in Sect. 3.2.

\subsection{Branching AP/NP predicates}

Let us determine first whether the [ $\mathrm{P} x$ ] generalization continues to hold in this domain. The examples below involve AP predicates; the same patterns are found with NP predicates, but space prevents me from illustrating this here. (47) and (48) show examples with resultative AP predicates: ${ }^{24}$
a. * dat Marie Jan met ze heel erg bang maakt that Marie Jan with them very much afraid makes
b. dat Marie Jan heel erg bang met ze maakt that Marie Jan very much afraid with them makes 'that Marie makes Jan very afraid with them'
c. * waar $_{\mathrm{i}}$ Marie Jan [PP mee $\mathrm{t}_{\mathrm{i}}$ ] heel erg bang maakt which Marie Jan with very much afraid makes
d. waar $_{i}$ Marie Jan heel erg bang [PP mee $\left.t_{i}\right]$ maakt which Marie Jan very much afraid with makes

\footnotetext{
${ }^{23}$ Observe, that the absence of V-movement entails that the analysis of PP-over- $\mathrm{V}$ without right-adjunction provided by Zwart (1993) is lost (cf. fn 22).

${ }^{24}$ Depictive secondary predicates show a different pattern than the predicative complements discussed here; they are presumably generated in a higher, adjoined position (see e.g. Winkler 1994 and references cited there); I leave them out of consideration here. Further SC cases might include naming constructions (Matushansky 2005); these seem to conform to the pattern found here.
} 
(48) a. dat Marie de schuur $<*$ met ze $>$ helemaal groen $<$ met ze $>$ verft that Marie the barn with them all green with them paints

b. waar ${ }_{i}$ Marie de schuur $<*\left[\right.$ PP mee $\left.t_{i}\right]>$ helemaal groen $<$ pP mee $\left.t_{i}\right]>$ verft which Marie the barn with all green with paints

The following examples are of small clauses selected by a (pseudo-)copula, and by a consider-type verb:

(49) a. dat Marie $<*$ door ze $>$ heel erg gelukkig $<$ door ze $>$ is geworden that Marie due-to them very much happy due-to them has become

b. waar ${ }_{i}$ Marie $<*$ [PP door $\left.t_{i}\right]>$ heel erg gelukkig $<$ [PP door $\left.t_{i}\right]>$ is geworden which Marie due-to very much happy due-to has become

(50) a. dat Marie de taalkunde $<*$ door je $>$ erg bijzonder $<$ door je $>$ is gaan

that Marie the linguistics due-to you very special due-to you has begun vinden

find

b. waar $_{\mathrm{i}}$ Marie de taalkunde $<*$ door $\mathrm{t}_{\mathrm{i}}>$ erg bijzonder $<$ door $\mathrm{t}_{\mathrm{i}}>$ is gaan vinden which Marie the linguistics due-to very special due-to has begun find

We observe that in each case, [ P x ] must be to the right of the SC predicate. I draw two conclusions from these data. First, the generalization that $[\mathrm{Pt}]$ occurs just where [ P pro ] occurs, remains valid; both occur only to the right of branching SC predicates.

Secondly, given the Freezing hypothesis, I conclude from (47) through (50) that in these structures, the unmarked position of the adverbial PP is to the right of the SC predicate. This results in the following unmarked order (extending (34) but omitting details irrelevant at this point; AP stands for the SC predicate, OB for the object/SCsubject):

$$
\text { OB APred } \mathrm{PP}_{\mathrm{Adv}} \mathrm{V}
$$

The reasoning is the same as in Sect. 2. If [ $\mathrm{Pt}$ ] is not taken to reveal the unmarked position of PP (Freezing), the alternative would be to derive the correct position for [ $\mathrm{P} \mathrm{t}$ ] by moving stranded $\mathrm{P}$; but such an analysis is difficult to extend to the [ $\mathrm{P}$ pro ] case, in the absence of a common movement trigger for [ $\mathrm{P} x$ ]. A fortiori, analyses like Hoekstra (1979), Zwart (1993), and Neeleman (1994), which derive the position of [ P t ] by head-movement of stranded P, cannot apply to [ P pro ].

Can the unmarked order in (51) be the underlying order? This seems unlikely, as it would entail that the SC predicate originates in a position further removed from the V-head than the adverbial PP. Furthermore, it can be shown with the same tests that PP SC predicates have their base position to the right of adverbial PPs (see Sect. 4); it is unlikely that PP SC-predicates and AP SC-predicates would be base-generated in different positions. In addition, an $\mathrm{AP}_{\text {Pred }}-\mathrm{PP}_{\mathrm{Adv}}-\mathrm{V}$ base order would not allow us to account for the order in (43a) where [ $\mathrm{P} \mathrm{t}$ ] may occur to the left of A, unless by scrambling of the stranded $\mathrm{P}$, which is disallowed. Hence, the underlying order must be PP - AP - V, the AP SC predicate in the well-formed cases of (47) through (50) having moved to the left of the adverbial PPs to derive the unmarked AP - PP - V order. This movement cannot be optional "scrambling": not only is it obligatory, but we also know from (44) that AP SC predicates generally do not scramble.

Let us therefore adopt the hypothesis that AP (and NP) SC predicates move to some functional projection, PredP, crossing the base position of the adverbial PP; 
I assume this satisfies a Case/Agreement requirement of the predicate. ${ }^{25}$ In adopting a PredP, I follow Zwart (1992, 1993, 1997), Koster (1994), and Hinterhölzl (2000), who make similar assumptions regarding SC predicate movement, although Koster's PredP is the target for movement of other material as well, hence not the locus of Case (I will return to these LCA-compliant analyses in Sect. 4.1; see Zwart (1993) for further discussion of PredP). In diagram (52), I have left the position of the Agent of maakte 'made' unspecified.

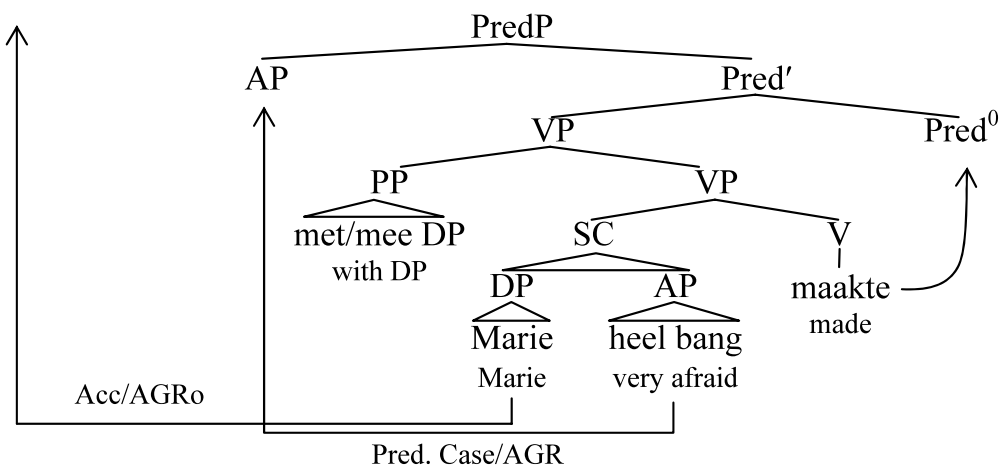

In addition to movement of the SC subject to its Case position, which must be in a functional projection higher than PredP, the AP moves to Spec,PredP, deriving the AP $-[$ P x ] - V order in (47)-(50), with the adverbial PP in its base position.

The derivation in (52) for the SC examples discussed so far is identical to the derivation of the [ P t ] cases proposed in Zwart (1997) (see (46)), except for my assumption that VP and PredP in (52) are right-headed, and violate the LCA. Not everything about (52) is essential to my proposal. What is not essential is the Small Clause structure; any other structure will do, as long as the predicate originates in the complement domain of the verb. What is essential is that there is at least one head-final projection. This will become apparent in the discussion of PP predicative complements in Sect. 4.1.

The assumptions so far derive the AP $-[\mathrm{P} x]-\mathrm{V}$ order. However, as mentioned above, PPs with a full NP complement, [ P NP ], may not occur in between AP and V (see $(53 \mathrm{c}))$ : that I Karel very afraid with them have made 'that I made Karel very afraid with them'
a. dat ik Karel heel bang met ze heb gemaakt
b. waar $_{i}$ ik Karel heel bang [PP mee $\left.t_{i}\right]$ heb gemaakt which I Karel very afraid with have made

\footnotetext{
${ }^{25}$ Morphological evidence suggesting that Small Clause predicates may receive their own Case comes from languages (e.g. Russian: Franks 1990; Bailyn and Rubin 1991) where these predicates can be casemarked without showing case-agreement with the SC subject:
}

(i) Maša sčitaet Ivan-a glup-ym. Russian; Ora Matushansky, p.c.

Mary considers John-Acc stupid-Instr 


c. * dat ik Karel heel bang met die poppen heb gemakt
that I Karel very afraid with those dolls have made
d. dat ik Karel met die poppen heel bang heb gemaakt
that I Karel with those dolls very afraid have made

How can we explain this restriction on the distribution of [ P NP ]? Zwart (1997: 104) suggests (but without providing evidence) that a prosodic constraint forces [ P NP ] to scramble leftward, so as to allow the SC predicate to form one prosodic domain with V; such a constraint would not apply to a stranded P. The [ P pro ] facts now show that this suggestion is on the right track: the contrast between (53a) and (53c), both containing a PP maximal projection differing only in prosodic weight, indicates that $(53 \mathrm{c})$ indeed does not violate a syntactic constraint but a prosodic one, sensitive to the prosodic contrast between [ P NP ] and [ P pro ]. I phrase Zwart's constraint as follows:

Predicate Adjacency Constraint (PAC) - to be revised

A predicative complement may not be prosodically separated from the verbal end cluster.

The PAC rules out (53c) with the adverbial [ P NP ] in its base position separating the $\mathrm{SC}$ predicate from the sentence-final verb cluster, given that an adverbial must form a separate intonational domain (see, e.g., Gussenhoven 1992; Winkler 1994). On the other hand, it allows stranded P and [ P pro ] to separate SC predicate and verb cluster in (53a) and (53b). The difference with (53c) is that these are elements that do not bear stress (see Halle and Vergnaud 1987: 264); I assume that they are invisible to the PAC.

Consider some further independent evidence. If a resultative secondary predicate, or other SC predicate, must belong to the same intonational domain as the verbal end cluster, this constraint should also be violated when the SC predicate has not moved across an adverbial, but constitutes a separate Intonational Phrase (IP) merely due to its own size. The contrast in (55) shows that this prediction holds.

a. * dat Jan de schutting groen, wat een mooie kleur is, heeft geverfd that Jan the fence green, which a nice color is, has painted

b. dat Jan Marie opgewekt, wat hij nu eenmaal altijd is, is gaan zoeken that Jan Marie cheerful, which he now after-all always is, is gone search 'that Jan went to look for Marie cheerful, which after all, he always is'

The appositive relative clause attached to the predicative complement in (55a) forms a separate IP, separating the head of the predicate from the verbal cluster. The structure is ruled out (it can be corrected by extraposing the $\mathrm{CP}$ ). (55b) shows that the constraint is not against a non-extraposed CP per se; the appositive CP may remain in situ when it modifies a depictive, which is not subject to (54).

The PAC as stated in (54) clearly cannot be the last word on the matter. I will return to it in Sect. 4.2, but a full discussion is outside the scope of this paper; see Ruys (in prep.). 


\subsection{Non-branching AP predicates}

I have argued that adverbial PPs occur to the right of branching AP predicative complements when they are [ P t ] or [ P pro ] because that is their base position. Let us now return to example (43), repeated here:

(43) a. waar ${ }_{i}$ Jan Marie [pp mee $t_{i}$ ] bang heeft gemaakt which Jan Marie with afraid has made 'which Jan has made Marie afraid with'

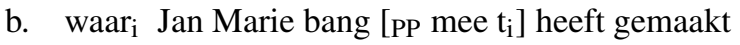
which Jan Marie afraid with has made

When the AP predicate does not branch, stranded P may sometimes occur either to its left or to its right. I predict that the same variation occurs with [ P pro ]:

(56) a. dat ik Karel met ze bang heb gemaakt that I Karel with them afraid have made

b. dat ik Karel bang met ze heb gemaakt that I Karel afraid with them have made

(57) a. dat ik de muur voor je groen heb geverfd that I the wall for you green have painted

b. dat ik de muur groen voor je heb geverfd that I the wall green for you have painted

This prediction is confirmed: once again, the distribution of [ $\mathrm{P}$ pro ] mirrors that of $[\mathrm{Pt}] .^{26}$

What allows the predicate to occur on either side of the PP? The A $-[\mathrm{Px}]-\mathrm{V}$ order in the b-cases of (43), (56) and (57) is already accounted for: this is the structure in (52), with the predicate moving to Spec,PredP. Just as with branching APs, the PP may not have a full NP complement, due to the Predicate Adjacency Constraint (54), as demonstrated in (41a). The problem is in explaining why the predicate may occur also to the right of the adverbial, yielding the [ $\mathrm{P} x$ ] $-\mathrm{A}-\mathrm{V}$ order of the a.-cases of (43), (56) and (57), and why this option is limited to non-branching predicates. The analysis in Zwart (1997), which I have largely followed in my account of branching AP predicates, does not provide a solution: Zwart assumes that the [ $\mathrm{P} \mathrm{t}]-\mathrm{A}-\mathrm{V}$ order occurs when PP is generated in a higher position than shown in (52); but this does not explain why the order is allowed only with non-branching APs. ${ }^{27}$ Worse, allowing adverbial PPs to be base-generated in various positions would tend to upset all our results.

\footnotetext{
${ }^{26}$ Some speakers have a preference for the b-examples (also in the [ $\left.\mathrm{Pt}\right]$ examples (43)). Crucially, though, the a-examples are acceptable, and considerably better than this order is with branching AP predicates.

${ }^{27}$ Recall that other analyses I have mentioned also fail to a greater or lesser degree: Zwart (1993), like Zwart (1997), allows base generation and stranding for $\mathrm{PP}_{\mathrm{Adv}}$ to the left of all secondary predicates in Spec,PredP, branching or otherwise; Neeleman (1994) stipulates a filter to block incorporation of stranded P into syntactically branching AP. See Sect. 4.1 below for a summing up on competing analyses.
} 
My approach allows two options here. One option is to claim that bang maken 'make afraid' and groen verven 'paint green' are separable A + V compound verbs. If so, the a.-cases do not contain an SC, and the PP may be base-generated to the left of $[\mathrm{v} A+\mathrm{V}]$, hence allowing [ $\mathrm{P} x$ ] there. Another option, which for concreteness I will tentatively adopt here, is that bang 'afraid' is an SC predicate which, instead of moving to Spec,PredP for feature-checking, adjoins to the verb and moves along with V-Raising, moving through the head of PredP and checking its features there.

Independent evidence that at least one of these options is available comes from the well-known fact that resultative predicates like bang 'afraid' may move along with the verb in verb-raising (Germanic clause union) constructions:

a. dat ik Karel $t_{i}$ wil [v bang maken $]_{i}$ that I Karel want afraid make-INF

b. dat ik de deur $t_{i}$ zal [v groen verven $]_{i}$ that I the door will green paint-INF

c. dat ik het touw $t_{i}$ zal moeten gaan $[\mathrm{v} \text { vast binden }]_{i}$ that I the rope will must go tight bind-INF 'that I shall have to go and fasten the rope'

Also, the resultative may combine with the verb to the right of the aspectual particle in the aan het construction (cf. De Rijk 1967):

a. ? Ik ben Karel aan het bang maken.

I am Karel at the afraid make-INF

'I'm frightening Karel.'

b. ? Ik ben de deur aan het groen verven.

I am the door at the green paint-INF

c. Ik ben het touw aan het vast binden.

I am the rope at the tight bind-INF

Note, that the $\mathrm{A}+\mathrm{V}$ incorporation/compounding analysis of the $[\mathrm{P} \mathrm{x}] \mathrm{A} \mathrm{V}$ order does not predict that $\mathrm{A}$ and $\mathrm{V}$ must remain adjacent under verb second and verb raising. Dutch has two types of compounding. So-called inseparable compounds (volbrengen, full-bring 'accomplish') always move as a unit in syntax. But with separable compounds (schoon maken, clean-make 'clean'; op bellen, up-call 'telephone') the left-hand member is stranded on verb second, and may optionally move along with verb raising, or be stranded at different positions in the chain headed by the raised verb (see Evers 2003 and references cited there for discussion). In this respect, the $\mathrm{A}+\mathrm{V}$ sequences that allow the $[\mathrm{P} \mathrm{x}]-\mathrm{A}_{\text {Pred }}-\mathrm{V}$ order in (43) show the same behavior as separable compounds: ${ }^{28}$

\footnotetext{
${ }^{28}$ Hinterhölzl (2000) observes that predicative complements occur outside the infinitival marker te 'to', and concludes they do not incorporate. But the same restriction holds for the left-hand part of separable compounds.
} 
(60) a. Ik verf er $_{i}$ de deur [PP mee $\left.t_{i}\right] \operatorname{rood} t_{j}$.

I paint $\mathrm{it}_{[+\mathrm{R}]}$ the door with red

'I paint the door red with it.'

b. dat $i k$ er $r_{i}$ de deur [PP mee $\left.t_{i}\right] \operatorname{rood} t_{j}$ wil verven $n_{j}$ that $\mathrm{I} \mathrm{it}_{[+\mathrm{R}]}$ the door with red want paint-INF

c. dat $\mathrm{ik} \mathrm{er}_{\mathrm{i}}$ de deur [PP mee $\left.\mathrm{t}_{\mathrm{i}}\right]_{\mathrm{j}}$ wil [rood verven $]_{j}$ that $\mathrm{I} \mathrm{it}_{[+\mathrm{R}]}$ the door with want red paint-INF

I assume that the process familiar from separable compounds has stranded the SCpredicate $A$ in (60a) and (60b) in Pred $^{0}$, or possibly in some higher head-position.

As for the choice between compounding and incorporation, the literature on separable $\mathrm{X}+\mathrm{V}$ sequences discusses both as analytic options. ${ }^{29}$ There are two reasons to prefer an incorporation account of the resultative $\mathrm{A}+\mathrm{V}$ sequences under discussion here. First, Neeleman (1994: 274) argues that whereas separable compound verbs are normally input to further morphological derivation (see (62a) below), A + V resultatives are not: *bang-maak-ing, 'afraid-make-ing'; *groen-verfbaar, 'green-paint-able'. ${ }^{30}$ Second, as pointed out to me by Mieke Trommelen (p.c.), a resultative adjective and a left-hand member of a separable compound cannot be coordinated in a right-node-raising structure: *bang- en af- maken, afraid- and offmake 'frighten and kill', which is possible with two separable compounds. For these reasons, I tentatively opt here for an incorporation account; but without any strong commitment, as a compounding account of these examples would also suffice to explain the $[\mathrm{P} x]-\mathrm{X}_{\text {Pred }}-\mathrm{V}$ order under discussion. Either option explains why the order of (43a) is blocked with full (branching) APs. On the compounding analysis, even though compounding (in particular, nominal compounding) with a syntactically branching constituent as the left-handed member is sometimes allowed, restrictions on verbal compounding in Dutch, discussed below, will prevent it here. On the incorporation account, we may postulate that the AP predicate must be both a maximal projection in order to occur as an SC predicate, and a head in order to undergo head movement, hence may contain only the head.

In the next section I will provide independent evidence for the proposed account of the [ $\mathrm{P} x$ ] A V order. I will argue that the [ $\mathrm{P} x$ ] A V order is allowed only if independent conditions on incorporation/compounding are met.

\footnotetext{
${ }^{29}$ See for instance Van Riemsdijk 1978; Koster 1975; Hoeksema 1991; Booij 1990; Neeleman 1994; Ackema 1995. Some authors (notably, Hoekstra et al. 1987; Hoekstra 1988, following Kayne 1984) have argued that $\mathrm{X}+\mathrm{V}$ sequences, even inseparable and prefixed verbs, all have a common Small Clause underlying form, and are derived through subsequent incorporation. Van Riemsdijk (1978), who discusses the case of adposition/particle $+\mathrm{V}$ at length, proposes an incorporation account for all except the inseparable cases (see also Bennis 1992; Hoeksema 1991; Den Dikken 1995); this incorporation process is however lexically governed, and sometimes blocked. Koster (1975) argues for a compounding approach. Booij (1990) describes the separable cases as a novel syntactic projection of V labelled $\mathrm{V}^{*}$, which is constructed in the lexicon.

${ }^{30}$ As an anonymous reviewer points out, this criterion is not watertight: some cases do allow further derivation (see Hoekstra 1984: 262), nor is further derivation of separable compounds fully productive.
} 


\subsection{Some conditions on compounding/incorporation}

Given my analysis of (43), which states that the [ P x ] A V order is due to incorporation or compounding, and raising of the $\mathrm{A}+\mathrm{V}$ complex to $\operatorname{Pred}^{0}$ (and beyond), I predict that these orders are possible just in case $\mathrm{A}+\mathrm{V}$ (or $\mathrm{N}+\mathrm{V}$ ) are allowed as compounding/incorporation structures, eligible for $\mathrm{V}$-raising. I state the expected generalization as $\mathrm{A}:{ }^{31}$

A. $\quad[\mathrm{Px}] \mathrm{A} / \mathrm{N} \mathrm{V}$ is allowed iff $\left[\mathrm{V}^{0} \mathrm{~A} / \mathrm{N} \mathrm{V}\right]$ is

In this section I will identify some of the conditions governing [ $\mathrm{V}^{0} \mathrm{~A} / \mathrm{N} \mathrm{V}$ ] compounding/incorporation, and argue that generalization A indeed holds. We will find that, where the secondary predicate cannot compound with/incorporate into the verb, due to prosodic restrictions (Sect. 3.3.1) or for other reasons (Sect. 3.3.2), the $[\mathrm{P} \mathrm{x}]-\mathrm{X}_{\text {Pred }}-\mathrm{V}$ order is blocked.

\subsubsection{Prosodic constraints on compounding/incorporation}

This section shows that the [ $\mathrm{P} x$ ] A V order is blocked when prosodic constraints block incorporation/compounding of $\mathrm{A}$ and $\mathrm{V}$. Both adjectival and verbal compounding in Dutch are subject to (prosodic) restrictions on the left-hand member (see De Haas and Trommelen 1993 and references cited there): derived, and even underived but prosodically heavy, left-hand members are disallowed in $\mathrm{X}+\mathrm{V}$ compounding. I state this as generalization B.1, illustrated in (61)-(62):

B. $1 \mathrm{X}+\mathrm{V}$ compounding/incorporation only allows prosodically 'light' and non-branching $\mathrm{X}$.
a. $\quad \mathrm{ei}_{\mathrm{N}}-\mathrm{geel}_{\mathrm{A}}$
b. $\quad *[\text { kwartel-ei }]_{\mathrm{N}}-$ geel $_{\mathrm{A}}$ egg-yellow quail's-egg -yellow
a. $\operatorname{schoon}_{\mathrm{A}}-\mathrm{maak}_{\mathrm{V}}$
$[\text { schoon-maak }-\varnothing]_{\mathrm{N}}$
[schoon-maak -er $]_{\mathrm{N}}$ clean-make, 'clean up' clean-make, 'cleaning $\mathrm{N}^{\prime}$ clean-make-er, 'cleaner'
b. $*\left[\left[[\text { brand-schoon }]_{\mathrm{A}}-\text { maak }\right]_{\mathrm{V}} \varnothing\right]_{\mathrm{N}}$ brand-clean-makeN
$*\left[\left[[\text { brand-schoon }]_{\mathrm{A}}-\text { maak }\right]_{\mathrm{V}}-\mathrm{er}\right]_{\mathrm{N}}$ brand-clean-make-er

\footnotetext{
${ }^{31}$ Generalization $\mathrm{A}$ does not appear in the literature, but the notion that a $[\mathrm{Pt}]-\mathrm{X}-\mathrm{V}$ order is allowed only if $X$ and $V$ form a close (semantic) unit, does. For instance, Koster (1994) allows stranded $\mathrm{P}$ and V to be separated by elements that occupy Spec,PredP, where they count as "incorporated" into the verbal element in $\operatorname{Pred}^{0}$; but such Spec-Head "incorporation" structures are not head-like, as required by generalization A. Earlier, Bennis (1986) (see also Bennis and Hoekstra 1984) had provided examples like (43), and stated that $[\mathrm{Pt}]-\mathrm{X}-\mathrm{V}$ is allowed when $\mathrm{X}$ is an inherent place/direction adverbial PP or a predicative complement, forming a verbal complex with $\mathrm{V}$, or when $\mathrm{X}$ is a dative or optional directional $\mathrm{PP}$, counting as "incorporated into" the verbal complex; but the notion of incorporation structure is not explicated, and there is no implication that the $\mathrm{X}+\mathrm{V}$ verbal complex should behave as a head for V-raising or obey conditions on incorporation/compounding (which would in fact fail, as $\mathrm{PP}+\mathrm{V}$ combinations do not obey generalization A). Similarly, Hoeksema (1991) states that where [ P t ] $-\mathrm{X}-\mathrm{V}$ is allowed, $\mathrm{X}$ and $\mathrm{V}$ form a "complex predicate"; but no tests for complex-predicatehood such as the possibility of V-raising are proposed.
} 
The A + V sequence brand-schoon maak 'make spotless' in (62b), with a complex left-hand member, is not allowed as a compound, but only as a sequence of separate syntactic heads: unlike schoon-maak in (62a), it does not allow further morphological derivation. The same restriction holds for inseparable $\mathrm{X}+\mathrm{V}$ compounds (for some exceptions, see Ackema 1995) and for X+A compounds (see (61)), supporting the existence of a prosodic restriction like B.1 in Dutch morphology.

Consider next generalization B.2, exemplified in (63) and (64):

B. $2 \mathrm{X}+\mathrm{V}$ sequences undergo $\mathrm{V}$-raising only if $\mathrm{X}$ is prosodically 'light', and non-branching.

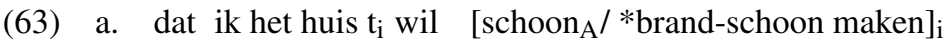
that I the house want clean / spotless make

b. ?? dat ik Marie $t_{i}$ wil [jaloers ${ }_{A}$ maken $]_{i}$ that I Marie want jealous make

(64) dat ik de deur $t_{i}$ wil $\left[\text { groen }_{\mathrm{A}} /{ }^{*} \mathrm{knal}-\mathrm{rood} / *^{*} \text { violet verven }\right]_{\mathrm{i}}$ that I the door want green/bright-red/violet paint

As (63) and (64) show, a 'light', simplex adjective may move along with verb raising in standard Dutch, but a compounded or merely prosodically heavy adjective may not. This restriction is well known from the literature. ${ }^{32}$ In fact, it has been used to support generalization B.1: under the assumption that all compounds may move with V-raising, the pattern (63a) has been taken as further evidence (besides the data in (62b)) that brand-schoon maken is not a compound, hence does not provide a counter-example to B.1. In this sense, the relation between B.1 and B.2 is at least implicitly present in the literature, although I am not aware of any explicit attempt to derive B.2 from B.1; Neeleman (1994), for instance, attributes B.2 to a separate ban on a $\varphi$-phrase intervening in a $\mathrm{V}$-cluster. ${ }^{33}$

My analysis of the [ $\mathrm{P} x$ ] X V order as derived through compounding or incorporation of $\mathrm{X}$ into $\mathrm{V}$, followed by movement into Pred $^{0}$, now predicts that this order will occur only if, prosodically, $\mathrm{X}$ is a candidate for incorporation or compounding. That is, given B.1 and B.2, generalization A leads us to expect that B.3 should hold:

B. $3[\mathrm{P} x] \mathrm{X} V$ sequences are allowed only if $\mathrm{X}$ is prosodically 'light' and non-branching.

While it is not reported in the literature, this generalization indeed appears to hold. We have already seen that [ P x ] AP V is disallowed when AP branches; but nonbranching APs consisting of only a head, which is however itself branching or prosodically 'heavy', also disallow the [ P x ] A V order:

\footnotetext{
${ }^{32}$ See, e.g., the discussion in Neeleman (1994); see Hoeksema (1993) for some discussion of diachronic and dialectal variation.

${ }^{33}$ Zwart (1993: 322) summarily dismisses an incorporation account of [ P x ] A V on the grounds that generalization B.2 is "a recent development, dating from the 19th century, [...] caused by stylistic rather than grammatical factors".
} 
(65) a. * waar ${ }_{i}$ ik de deur [pP mee $t_{i}$ ] knalgroen/violet verf which I the door with bright-green/violet paint

b. * dat ik de deur met ze knalgroen/violet verf that I the door with them bright-green/violet paint

(66) a. waar ${ }_{i}$ ik de deur knal-groen/violet [PP mee $t_{i}$ ] verf which I the door bright-green/violet with paint

b. dat ik de deur knal-groen/violet met ze verf that I the door bright-green/violet with them paint

The prediction is confirmed: since compounding/incorporation in (65) is ruled out by the prosodic constraints demonstrated by B.1 and B.2, the adjective must be a separate AP, and move leftwards to Spec,PredP, across [ P x ], yielding the A [ P x ] $\mathrm{V}$ order of (66). ${ }^{34}$ Observe also that the $[\mathrm{P} \mathrm{x}$ ] generalization is again confirmed by (65) and (66).

The generalizations B.1, B.2 and B.3 as they apply to resultative predicative complements can be explained straightforwardly with a compounding analysis. If all verbal compounds are subject to the relevant prosodic constraint B.1, and verb raising allows only movement of morphological verbs, then the ill-formed cases of (63) and (64) are excluded - deriving B.2 — and, given my analysis of [ P x ] A V, so is (65) deriving B.3. Nonetheless, in view of the evidence against a compounding analysis mentioned at the end of Sect. 3.2 above (in fact, as far as I know, a compounding analysis has never been proposed in the literature for these cases, although it is reasonable to suppose Koster (1975) might have taken this position had he discussed them as a separate class), I adopt a syntactic (incorporation) account as well. I assume, therefore, that incorporation into verbs is subject to the same prosodic restrictions that govern verbal compounding (see Baker 1988: 71; see also Stowell 1982), thereby accounting for (63) and (64) and, under my assumptions on the distribution of $[\mathrm{P} x],(65)$.

\subsubsection{Incorporation of other predicative complements}

My second test of generalization A makes use of predicate complement types that resist incorporation. The word order variation between [ $\mathrm{P} x$ ] and A seen in (43) is found mostly with resultatives, and the previous section focused on the [ $\mathrm{P} \times \mathrm{x}$ ] A V incorporation pattern that occurs with resultative secondary predicates. But not

\footnotetext{
(i) a. dat Marie zich $t_{i}$ heeft $[v(* \text { dood }) \text { suf gepiekerd }]_{i}$ that Mary SE-anaphor has dead-dull worried

b. dat Marie zich over ze (*dood)suf heeft gepiekerd that Mary SE-anaphor about them dead-dull has worried

c. waar ${ }_{i}$ Marie zich [over $\left.t_{i}\right](*$ dood)suf heeft gepiekerd which Mary SE-anaphor about dead-dull has worried
}

${ }^{34}$ The pattern persists with resultative small clauses occurring with unergative verbs and 'fake reflexives' (Simpson 1983; Hoekstra 1988). When the predicate does not branch syntactically and is not prosodically heavy or morphologically compounded, it sometimes allows the [ $\mathrm{P} \mathrm{x}] \mathrm{A} \mathrm{V}$ order, as well as verb-raising: 
all secondary predicates allow incorporation. Predicates in consider-verb complements, which are more generally recognized as small clause constructions, do not (see Neeleman 1994: Ch. 5 for discussion). This is demonstrated by the fact that they do not move with verb-raising. (67) shows this for dom vinden 'consider foolish':

(67) dat de mensen Jan $<$ dom $>t_{i}$ zullen gaan $[\mathrm{v}<* \text { dom }>\text { vinden }]_{\mathrm{i}}$ that the people Jan $<$ foolish $>$ will begin-to $<$ foolish $>$ find

As generalization A now predicts, only the A [ $\mathrm{P} x$ ] V order is allowed with considercomplements; the [ P x ] A V order is blocked (see esp. Neeleman 1994):

(68) a. dat de mensen Jan $<$ dom $>$ [pP door ze] $<*$ dom $>$ zullen gaan vinden that the people Jan $<$ foolish $>$ due.to them $<$ foolish $>$ will begin.to find

b. de opmerking waar ${ }_{i}$ ze Jan $<$ dom $>$ [PP door $\left.t_{i}\right]<*$ dom $>$ zullen gaan vinden the remark which $\mathrm{i}_{\mathrm{i}}$ they Jan $<$ foolish $>$ due.to $<$ foolish $>$ will begin.to find 'the remark due to which they will begin to consider Jan foolish'

The permissible order in (68) follows from AP movement into Spec,PredP; the proscribed order would follow from incorporation of dom (or compound-formation).

I have no explanation to offer for the impossibility of incorporating considercomplements, which may be due to a selectional property of the verb, but the resulting [ $\mathrm{P}$ x ] pattern is as expected. The same pattern exists with other predicative complement types. For instance, verbs of naming (e.g., gek noemen 'call foolish') also disallow V-raising of the secondary predicate, and the [ P x ] A V order; (pseudo-) copulas sometimes allow V-raising, and then allow [ $\mathrm{P} x$ ] A V.

My final test of generalization A involves nominal predicative complements. Nominal resultatives, unlike adjectival resultatives, are not allowed as compounds, and do not allow incorporation. This is shown independently by the fact that they do not move along with verb raising (and are disallowed to the right of the aan het aspectual particle):
dat Marie haar man $<$ vader $>\mathrm{t}_{\mathrm{i}}$ wilde $[\mathrm{v}<* \text { vader }>\text { maken }]_{\mathrm{i}}$
that Marie her husband <father $>$ wanted $<$ father $>$ make-INF 'that Marie wanted to make her husband father'

Consequently, these resultatives must move to Spec,PredP, so occur only to the left of $[\mathrm{P} x]$ :
a. waar $_{i}$
Marie haar man
vader [PP mee $t_{i}$ ]
maakt
b. dat
Marie haar man
vader
met ze
maakt
$\left\{\right.$ which $_{\mathrm{i}} /$ that $\}$ Marie her husband father with $\left\{\mathrm{t}_{\mathrm{i}} /\right.$ them $\}$ makes
a. $*$ waar $_{i}$
Marie haar man [PP mee $t_{i}$ ]
vader maakt
b. * dat
Marie haar man
met ze
vader maakt
$\left\{\right.$ which $_{\mathrm{i}} /$ that $\}$ Marie her husband with $\left\{\mathrm{t}_{\mathrm{i}} /\right.$ them $\}$ father makes

I will assume that the restrictions on incorporation at work here are lexically governed, and will not discuss them further. The important observation is that Generalization $\mathrm{A}$ and the $[\mathrm{P} \mathrm{x}]$ generalization are again confirmed.

To summarize, I assumed in Sect. 3.2 that the [ P x ] A V pattern in (43a) (repeated), which apparently contradicts the unmarked $\mathrm{AP}_{\text {Pred }} \mathrm{PP}_{\mathrm{Adv}} \mathrm{V}$ order established in Sect. 3.1, arises when AP does not move to Sped,PredP, but instead moves 
along with $\mathrm{V}$ to $\operatorname{Pred}^{0}$. This analysis predicts that generalization A (repeated also) should hold.

a. waar $_{i}$ Jan Marie [PP mee $t_{i}$ ] bang heeft gemaakt which Jan Marie with afraid has made 'which Jan has made Marie afraid with'

A. $\quad[\mathrm{Px}] \mathrm{A} / \mathrm{N} \mathrm{V}$ is allowed iff $\left[\mathrm{V}^{0} \mathrm{~A} / \mathrm{N} \mathrm{V}\right]$ is

I have shown that this is correct: when prosodic constraints (the B.-generalizations of Sect. 3.3.1) or apparent lexical constraints block compounding or incorporation of $\mathrm{A} / \mathrm{N}$ into $\mathrm{V}$, the [ $\mathrm{P} \mathrm{x}$ ] $\mathrm{A} / \mathrm{N} \mathrm{V}$ order is blocked. In addition, the [ $\mathrm{P} \mathrm{x}$ ] generalization has been upheld throughout. ${ }^{35}$

\section{PP Small Clauses}

This final section discusses PP predicative complements. The unmarked position of $\mathrm{PP}_{\text {Pred }}$ is to the right of $\mathrm{PP}_{\mathrm{Adv}}$, as indicated in (40) (repeated).

$$
\left(\mathrm{AP}_{\text {Pred }}\right) \quad \mathrm{PP}_{\mathrm{Adv}}\left(\mathrm{PP}_{\text {Pred }}\right) \mathrm{V}
$$

I will establish this base order by means of the [ P x ] test in Sect. 4.1. Section 4.2 discusses the marked orders which can arise when PPPred scrambles, and shows that these provide further evidence for (a modified) Predicate Adjacency Constraint (54).

\subsection{PP predicates and the $[\mathrm{P} x]$ test}

We have seen that with AP (and NP) SC predicates, the position of adverbial [ P x ] is restricted as follows. When AP branches, [ $\mathrm{Px}$ ] must occur to its right; otherwise, [ P x ] may sometimes occur on either side. When the SC predicate is a PP (a "complementive" PP in Broekhuis 2002), we expect to find a different pattern. Consider again the underlying structure I postulate, now with a PP predicate $((72)=(77)$; again, the Small Clause is not crucial to the analysis; the violation of the LCA is, as will be explained below).

Recall, that the AP - [ P x ] - V order is derived when AP moves to Spec,PredP for Case/Agreement checking. This approach predicts that PP-predicates, which we have assumed are not involved in Case relations, do not move to the left, but remain to the right of adverbial PPs, as indicated in (72). As a result, we expect that

\footnotetext{
(i) a. dat ik mijn besluit wil kenbaar/ ?ongedaan maken that I my decision want knowable / undone make-INF 'that I want to make my decision known / reverse my decision'

b. waar $_{i}$ ik mijn besluit [PP mee $\left.t_{i}\right] \operatorname{kenbaar}_{\mathrm{A}} /$ ?ongedaan $_{\mathrm{A}}$ wil maken which I my decision with knowable/undone make-INF
}

${ }^{35}$ Some exceptional cases provide further evidence. Hoeksema (1993) notes that Standard Dutch sometimes allows more than just light adjectives or particles to move along with Verb Raising (a process known as Verb Projection Raising (see Haegeman and van Riemsdijk 1986), common in for instance Flemish and Zürich German and in older stages of Standard Dutch). In Standard Dutch, this is apparently restricted to fixed expressions and idioms. As we would expect, such cases allow the [ P x ] Pred V order as well: 


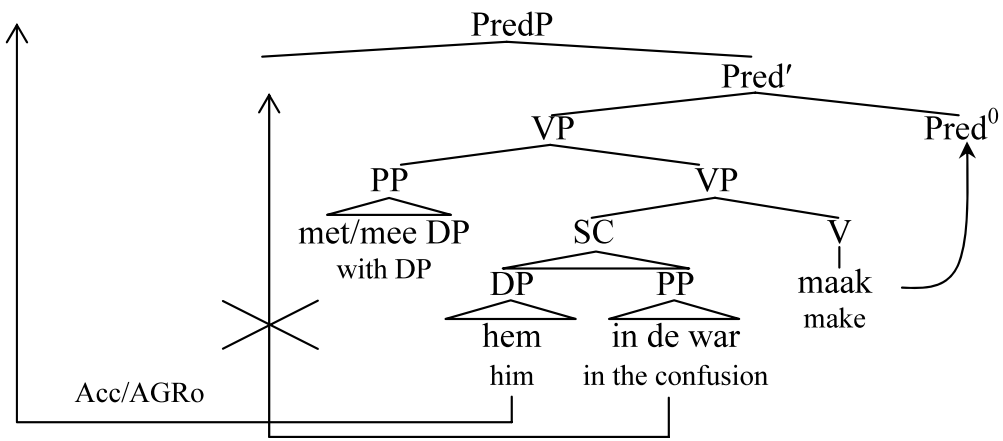

the unmarked order will be $\mathrm{PP}_{\mathrm{Adv}}-\mathrm{PP}_{\text {Pred }}-\mathrm{V}$, the opposite of the unmarked $\mathrm{AP}_{\text {Pred }}-\mathrm{PP}_{\mathrm{Adv}}-\mathrm{V}$; and this is exactly what we will find. I will establish the unmarked $\mathrm{PP}_{\mathrm{Adv}}-\mathrm{PP}_{\mathrm{Pred}}-\mathrm{V}$ order in two ways: by showing that $\mathrm{PP}_{\mathrm{Adv}}$ may be $[\mathrm{P} \mathrm{x}$ ] on this order, and by showing that the PP predicate itself may be [ $\mathrm{P} x$ ] on this order, but not on the opposite order.

Consider first the expected $[\mathrm{P} \mathrm{x}]_{\mathrm{Adv}}-\mathrm{PP}_{\text {Pred }}-\mathrm{V}$ pattern. This is indeed allowed:
a. waari $_{i}$
Jan de spijker mee $t_{i}$
in de muur heeft geslagen
b. dat
Jan de spijker met 'm
in de muur heeft geslagen
$\left\{\right.$ which $_{\mathrm{i}} /$ that $\}$ Jan the nail with $\left\{\mathrm{t}_{\mathrm{i}} / \mathrm{him}\right\}$ into the wall has hit
a. waar $_{i}$
Marie mee $\mathrm{t}_{\mathrm{i}}$
b. dat
Marie met ze
naar Amsterdam is gegaan
naar Amsterdam is gegaan
$\left\{\right.$ which $_{\mathrm{i}} /$ that $\}$ Marie with $\left\{\mathrm{t}_{\mathrm{i}} /\right.$ them $\}$ to Amsterdam is gone

As (73) and (74) illustrate, directional PP-complements may intervene between adverbial [ $\mathrm{P} \mathrm{x}$ ] and V. For the [ $\mathrm{Pt}$ ] case, this constitutes a well-known exception to the usual V-adjacency of stranded P (cf. Bennis and Hoekstra 1984; Bennis 1986; (73a) is based on Neeleman 1994: 202 (46a)). However, the pattern is more general: other predicative PPs (locationals, resultatives, consider-complements) may also intervene between [ P x ] and V (cf. also Neeleman 1994: 202): ${ }^{36}$

\footnotetext{
${ }^{36}$ Further evidence comes from particles. Like PPs, these are not expected to move to Spec,PredP for Case/Agreement. So the order $[\mathrm{P} \mathrm{x}]_{\mathrm{Adv}}-\mathrm{Part}-\mathrm{V}$ should be allowed, even when the prosodic constraint B.2 of Sect. 3.3.1 prevents the particle from compounding or incorporating (thus, ondersteboven in (i) is too heavy to move with verb-raising: *zal ondersteboven gooien). Likewise, Van Riemsdijk's (1978: 51ff) intransitive prepositions, which never incorporate, should nonetheless occur between $[\mathrm{P} \mathrm{x}]_{\mathrm{Adv}}$ and $\mathrm{V}$. Both predictions are borne out, as shown in (i) and (ii), respectively:
}
(i) a. waar ${ }_{i} \quad \mathrm{ik}$ de kegels [pP mee $\left.t_{i}\right]$ ondersteboven $n_{\text {part }}$ heb gegooid

b. dat ik de kegels met ze ondersteboven $n_{\text {part }}$ heb gegooid
\{which $_{\mathrm{i}} /$ that $\}$ I the skittles with $\left\{\mathrm{t}_{\mathrm{i}} /\right.$ them $\}$ upside-down have thrown

(ii) het doel waar ${ }_{i}$ Jan [PP voor $\left.t_{i}\right]$ boven blijft wonen

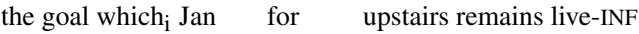



a. waar $_{\mathrm{i}}$
ik Jan voor $t_{i}$
in de steek liet
b. dat
ik Jan voor ze
in de steek liet

$\left\{\right.$ which $_{\mathrm{i}} /$ that $\} \mathrm{I}$ Jan for $\left\{\mathrm{t}_{\mathrm{i}} /\right.$ them $\}$ in the lurch left
a. waari
ik voor $t_{i}$
in Amsterdam ben
b. dat
ik voor ze in Amsterdam ben
\{which $/$ that $\}$ I for $\left\{\mathrm{t}_{\mathrm{i}} /\right.$ them $\}$ in Amsterdam am
a. waar $i_{i} i k$ hem mee $t_{i}$ in de war maak which I him with in the confusion make 'which I confuse him with'

b. dat ik hem met ze in de war maak that I him with them in the confusion make

Turning to the second test, the distribution of [ $\mathrm{P} x$ ] PP-predicates confirms that $\mathrm{PP}_{\mathrm{Adv}}-\mathrm{PP}_{\text {Pred }}-\mathrm{V}$ is the unmarked order. This order, in the a.-variants below, allows $[\mathrm{P} \times]_{\text {Pred }}$. The opposite order in the b.-variants does not. Observe that I need to use [ P x ] forms for the adverbial PP as well, or the PAC (54) will block leftward scrambling of the predicate (see the next section for discussion); this makes the examples awkward, but the contrasts are clear. ${ }^{37}$

a. Jan zet er bloemen met ze in $t_{i}$. Jan puts $\mathrm{it}_{[+\mathrm{R}] i}$ flowers with them in $\mathrm{t}_{\mathrm{i}}$

b. * Jan zet er bloemen in ze mee $\mathrm{t}_{\mathrm{i}}$. Jan puts $\mathrm{it}_{[+\mathrm{R}] i}$ flowers in them with $\mathrm{t}_{\mathrm{i}}$

(79) a. de buisjes waar ${ }_{i}$ Jan alleen dit voor je in $t_{i}$ heeft gedaan the tubes which $_{i}$ Jan only this for you in $t_{i}$ has put

b. * de buisjes waar $r_{i}$ Jan alleen dit in $t_{i}$ voor je heeft gedaan the tubes which $_{\mathrm{i}}$ Jan only this in $\mathrm{t}_{\mathrm{i}}$ for you has put

(80) a. ? de mensen waar ${ }_{i}$ Jan alleen dit voor $t_{i}$ in ze heeft gedaan, in die buisjes

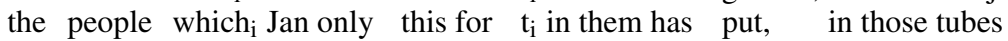

b. ?? de mensen waar ${ }_{i}$ Jan alleen dit in ze voor $t_{i}$ heeft gedaan, in die buisjes the people which $_{i}$ Jan only this in them for $t_{i}$ has put, in those tubes

Given the Freezing hypothesis, the distribution of $[\mathrm{P} x]_{\mathrm{Adv}}$ and the distribution of $[\mathrm{P} x]_{\text {Pred }}$ both show that $\mathrm{PP}_{\mathrm{Adv}}-\mathrm{PP}_{\text {Pred }}-\mathrm{V}$ is the unmarked order. We thus obtain the following extension of (34) (suppressing irrelevant details):

$$
\begin{array}{lll}
\mathrm{DP}_{\text {Arg }} & \mathrm{AP}_{\text {Pred }} \mathrm{PP}_{\text {Adv }} & \mathrm{PP}_{\text {Pred }} \mathrm{V} \\
& \mathrm{NP}_{\text {Pred }} & \mathrm{PP}_{\text {Arg }}
\end{array}
$$

This unmarked order follows from the analysis presented. Whether or not one adopts a Small Clause analysis, the predicative PP can be assumed to be first-merged in the complement domain of V. Since PP Pred does not need to move for Case/Agreement reasons, it stays to the right of $\mathrm{PP}_{\mathrm{Adv}}$. Recall that Sect. 2 put forward similar observations regarding argument PPs: they do not check case, hence remain to the right of

\footnotetext{
${ }^{37}$ Furthermore, extraction from predicative PPs is generally limited to locational and directional PPs (see Broekhuis 2002 for an overview).
} 
adverbials. The correct patterns are achieved, then, by equating the unmarked positions with the base-generated positions of $\mathrm{PP}_{\text {Pred }}$ and $\mathrm{PP}_{\mathrm{Arg}}$. The fact that these unmarked positions are nonetheless to the left of $\mathrm{V}$ is accounted for by the assumption that VP is head-final (Koster 1975), or that V moves to a right-headed FP (or both), as indicated in (52) and (72) above. Observe, finally, that the [ P x ] generalization is once again confirmed by the data cited above.

Consider briefly some previous analyses. Bennis and Hoekstra (1984), Bennis (1986), Hoeksema (1991), and Neeleman (1994) all assume that, for different reasons, stranded P must be V-adjacent. In order to account for the intervention of directional PPs (and other predicative PPs) between stranded $\mathrm{P}$ and $\mathrm{V}$, these authors assume the same explanation they propose for the $[\mathrm{P} t]-\mathrm{A}_{\text {light }}-\mathrm{V}$ pattern discussed in the previous section: the intervening A or PP forms a "complex predicate" with V, or is "incorporated" into V. However, as pointed out earlier (see note 31), unlike light adjectival secondary predicates, PP secondary predicates show no syntactic signs of incorporation. In fact, $A_{\text {Pred }}$ and $P_{P \text { Pred }}$ do not behave alike at all. Light adjectival predicates move along with $\mathrm{V}$-raising, PP secondary predicates may not. And adjectival predicates obey the A-generalization (see Sect. 3.3): they must be light and nonbranching in order to incorporate, and may not incorporate, e.g., in consider-verbs; PP predicates intervening between stranded $\mathrm{P}$ and $\mathrm{V}$ may be branching and heavy, even have left-hand modifiers, and the pattern persists with consider-verbs all. Describing both classes as "incorporation" or "complex predicates" would void these notions of empirical content, and provide no explanation for their distinctive behavior. For instance, Neeleman (1994) states that whereas stranded P cannot incorporate into a branching AP, it can incorporate into a branching PP, a stipulation that remains unexplained. My analysis allows predicative PPs to intervene between stranded $\mathrm{P}$ and $\mathrm{V}$, not by assimilating them to $\mathrm{A}_{\text {light }}$, but by treating them as ordinary secondary predicates, which happen not to be involved in Case/Agreement relations.

As for Zwart (1992, 1993, 1997) and Koster (1994), I borrow from these analyses the use of a PredP functional projection. However, these authors also adopt a VO underlying structure, and obtain the preverbal position of all predicates, including PPs, via movement to Spec,PredP. As a result, they do not derive the fact that the unmarked position of PP predicates is not the same as that of AP predicates, but on the opposite side of PP adverbials; likewise for PP arguments. Whether an LCAcompliant analysis of the pattern in (81) can be defended is a question that I must leave for future research to address.

\subsection{PP scrambling, predicates, and the PAC}

This section briefly examines the conditions on $\mathrm{PP}_{\text {Pred }}$ scrambling, and shows that PP predicates, like AP predicates, obey a modified version of the Predicate Adjacency Constraint (54). In the previous section, I argued that the unmarked position of PP Pred is $\mathrm{V}$-adjacent, to the right of $\mathrm{PP}_{\mathrm{Adv}}$. The opposite order, which would result from leftward scrambling of $\mathrm{PP}_{\text {Pred }}$, therefore does not allow $\mathrm{PP}_{\text {pred }}$ to be $[\mathrm{P} \mathrm{x}]$ (see (78)-(80)). When $\mathrm{PP}_{\text {Pred }}$ is not [ P x ], on the other hand, scrambling is sometimes allowed (if it were not, its unmarked position would be established immediately). 
The PAC (54) predicts that scrambling a PP predicate across an adverbial, away from the verb cluster, should be blocked in general. This prediction is correct, as the following data show ((82) from Bennis and Hoekstra 1984):

* dat we naar Groningen gisteren gingen

that we to Groningen yesterday went

(83) a. * dat Jan de spijker in de muur met de hamer heeft geslagen that Jan the nail into the wall with the hammer has hit

b. * dat Jan in Amsterdam met de meisjes is geweest that Jan in Amsterdam with the girls is been 'that Jan has been in Amsterdam with the girls'

If (82) and (83) are indeed blocked because the PP predicate must be prosodically adjacent to the verb, we expect that the structure is allowed when the intervening adverbial is prosodically light [ $\mathrm{Px}$ ]. This is confirmed by (84)-(86): ${ }^{38}$
a. ? waari
Jan de spijker in de muur mee $t_{i}$
heeft geslagen
b. ? dat
Jan de spijker in de muur met ze
heeft geslagen
$\left\{\right.$ which $_{\mathrm{i}} /$ that $\}$ Jan the nail into the wall with $\left\{\mathrm{t}_{\mathrm{i}} / \mathrm{them}\right\}$ has hit
a. ? waari
Jan in de kuil voor $t_{i}$
is gesprongen
b. ? dat
Jan in de kuil voor je
is gesprongen
$\left\{\right.$ which $\left._{\mathrm{i}} / \mathrm{that}\right\}$ Jan into the ditch for $\left\{\mathrm{t}_{\mathrm{i}} / \mathrm{you}\right\}$ is jumped
a. ? waari
Jan in Amsterdam mee $t_{i}$
is geweest
b. ? dat
Jan in Amsterdam met ze
is geweest
$\left\{\right.$ which $_{\mathrm{i}} /$ that $\}$ Jan in Amsterdam with $\left\{\mathrm{t}_{\mathrm{i}} /\right.$ them $\}$ is been

The situation is the same as with $\mathrm{AP}_{\text {Pred, }}$, which may also be separated from $\mathrm{V}$ by [ P x ] - see (53a), (53b). ${ }^{39}$ However, while the leftward movement of AP Pred is obligatory movement for Case/Agreement, the findings of the previous section show that the leftward movement of PPPred in (84)-(86) must be optional scrambling. This explains why $\mathrm{PP}_{\text {Pred }}$ may not be $[\mathrm{P} \mathrm{x}]$; and if the $\mathrm{PP}_{\text {Pred }}-\mathrm{PP}_{\mathrm{Adv}}$ order were due to obligatory movement, $[\mathrm{P} \times]_{\mathrm{Adv}}$ should be blocked on the opposite order. Also, a scrambling analysis fits better with the slightly marked status of the examples. Observe, that this analysis removes the last remaining evidence for a V-adjacency account of P-stranding in (9b)/(9c) (Sect. 1.1).

Further evidence that PP predicates are eligible for scrambling comes from the observation that they may scramble to even higher positions ((87a) from Broekhuis (2002)):

${ }^{38}$ The same order occurs with particles (cf. note 36 above):

(i) waar $_{\mathrm{i}} \mathrm{ik} \mathrm{de}$ man weg/binnen mee $_{\mathrm{i}} \mathrm{t}_{\mathrm{j}}$ heb gebracht

which I the man away/inside with have taken

'which I took the man away/inside with'

${ }^{39}$ As in the case of AP predicates, the examples with [ $\mathrm{P} \mathrm{t}$ ] intervening between PP predicate and $\mathrm{V}$ were attributed to rightward head-movement of P by Hoekstra (1979) (cf. (9b) above) and Neeleman (1994); as before, this does not extend to the [ P pro ] cases. 
(87) a. dat Jan [in elke vaas $]_{i}$ een roos $t_{i}$ stopte that Jan into every vase a rose put

b. dat Jan op elke plank wel eens een boek heeft gelegd that Jan on every shelf prt once a book has put

It appears that the need to contrastively focus the predicate PP, or to assign it scope over some argument (an observation due to Broekhuis (2002: 227)), licenses scrambling for these PPs. This is confirmed by the contrast with (88), where no scope effect occurs:

\section{?? dat Jan [op de plank $]_{i}$ het boek $t_{i}$ heeft gelegd \\ that Jan on the shelf the book has put}

I cannot enter into a full discussion here of the conditions under which secondary predicates may undergo scrambling, except to point out an immediate problem caused by (87). The examples force a rethinking of the PAC (54) (which was confirmed by (82), (83), and the contrast with (84)-(86)). In (87), the SC-predicate is separated from the verbal cluster by the object, and an adverb. How can the PAC be rephrased so as to allow these cases? I argue in Ruys (in prep.) that (87) is allowed because, even though the predicative PP is separated from the verb cluster, the object (SC subject) DP is not; a violation occurs only if both are separated from the verb:

(89) Predicate Adjacency Constraint (PAC)—revised from (54)

A predicative complement and its subject may not both be prosodically separated from the verbal end cluster.

Space prevents me from discussing here the derivation of (89) from underlying principles; I argue in Ruys (in prep.) that moving the SC subject or predicate triggers a prosodic repair operation which cannot apply twice. But consider one piece of independent evidence:

(90) a. dat Jan een vaasje met een hijskraan op de plank heeft gezet that Jan a vase with a crane on the shelf has put

b. dat Jan [op iedere plank $]_{i}$ een vaasje $t_{i}$ heeft gezet that Jan on every shelf a vase has put

c. * dat Jan [op iedere plank $]_{i}$ een vaasje met een hijskraan $\mathrm{t}_{\mathrm{i}}$ heeft gezet that Jan on every shelf a vase with a crane has put

(90a) shows that an object (SC subject) may occur to the left of an instrumental PP, due to movement to Spec,AGRo. (90b) again shows that a predicative complement PP in turn may scramble to the left of the object (the SC subject); the process is facilitated by its effect on scope relations. By simple transitivity, we would now expect that the object may move to the left of an instrumental PP, and the PP predicate to the left of the object, as in (90c). But this order is ruled out. On a purely syntactic approach, the ill-formedness of (90c) entails a near ordering paradox. ${ }^{40}$ The prosodic constraint (89) however exactly predicts the pattern in (90). See Ruys (in prep.) for further discussion.

\footnotetext{
${ }^{40}$ A Minimality approach that would block movement of PP across another PP would clearly fail, as PPs otherwise freely scramble across each other.
} 


\section{Conclusion}

In this paper I have argued that the generalization stated in (14) holds for Dutch.

\section{(14) The [ P x ] generalization}

[ P t ] may occur only where [ P pro ] may occur.

I have argued that the distribution of stranded $\mathrm{P}$ and $\mathrm{P}$ with weak pronominal complement can best be explained by assuming that they are restricted to the unmarked position of PP. I have also argued that the observed unmarked positions of PPs are best explained by positing no obligatory movements for PPs; if so, their unmarked positions are their base positions. As a result, [ $\mathrm{P} \mathrm{t}$ ] and [ $\mathrm{P}$ pro ] can be employed to determine the unmarked, base positions of argumental, predicative, and adverbial PPs in the Dutch Mittelfeld. Preliminary results indicate this order to be as stated in (91):

$\begin{array}{lllll}\text { OB } & \mathrm{AP}_{\text {Pred }} & \mathrm{PP}_{\text {Instr }} & \mathrm{PP}_{\text {by }} & \mathrm{PP}_{\text {Arg }} \quad \mathrm{V} \\ \text { NEG } & & & \mathrm{PP}_{\text {Ben }} & \mathrm{PP}_{\text {Dat }} \\ & & & \mathrm{PP}_{\text {Dir }} \\ & & & \mathrm{PP}_{\text {Pred }}\end{array}$

Such results can be used to support a cartographic approach to adverbial positions. They reflect on the base positions of other elements as well, notably DP-objects (for which an obligatory Case-movement analysis is confirmed) and predicative complements (which also undergo Case-movement when AP or NP). The resulting analysis of predicative complement constructions violates the LCA: Dutch is SOV underlyingly (Koster 1975). Further research should involve confirming the crosslinguistic validity of the $[\mathrm{P} x$ ] generalization, and confronting the results obtained here with different diagnostic types. Also, the role of prosodic constraints on word order in the Dutch Mittelfeld requires further elaboration.

Acknowledgements Thanks are due to Sjef Barbiers, Marcel den Dikken, Jan Don, Arnold Evers, Roland Hinterhölzl, Johan Kerstens, Ora Matushansky, Mieke Trommelen, audiences at the 2005 TINdag and the UMR 7023 colloquium at Paris 8, and three anonymous reviewers for discussion, suggestions, and comments on earlier versions. All remaining errors are of course my own.

Open Access This article is distributed under the terms of the Creative Commons Attribution Noncommercial License which permits any noncommercial use, distribution, and reproduction in any medium, provided the original author(s) and source are credited.

\section{References}

Abels, Klaus. 2001. *[P clitic]!-Why? Paper presented at the 4th European conference on formal description of Slavic Languages, Potsdam, University of Potsdam, November 28-30.

Abels, Klaus. 2003. Successive cyclicity, anti-locality, and adposition stranding. PhD dissertation, University of Connecticut.

Ackema, Peter. 1995. Syntax below zero. PhD dissertation, Utrecht University.

Baart, Joan. 1987. Focus, syntax and accent placement. PhD dissertation, Leiden University.

Bailyn, John, and Edward J. Rubin. 1991. The unification of instrumental case assignment in Russian. In Cornell working papers in linguistics, Vol. 9, eds. Almeida Toribio and Wayne Harbert, 99-126. Ithaca: Department of Modern Languages and Linguistics, Cornell University. 
Baker, Mark. 1988. Incorporation: a theory of grammatical function changing. Chicago: University of Chicago Press.

Barbiers, Sjef. 1995. The syntax of interpretation. The Hague: Holland Academic Graphics.

Bennis, Hans. 1986. Gaps and dummies. Dordrecht: Foris.

Bennis, Hans. 1992. Long head movement: the position of particles in the verbal cluster in Dutch. In Linguistics in the Netherlands 1992, eds. Reineke Bok-Bennema and Roeland van Hout, 37-47. Amsterdam: John Benjamins.

Bennis, Hans, and Teun Hoekstra. 1984. Gaps and parasitic gaps. The Linguistic Review 4: 29-87.

Booij, Geert. 1990. The boundary between morphology and syntax: separable complex verbs in Dutch. In The yearbook of morphology 3, eds. Geert Booij and Jaap van Marle, 45-63. Dordrecht: Foris.

Broekhuis, Hans. 2002. Adpositions and adpositional phrases. Modern grammar of Dutch occasional papers 3. Tilburg University.

Cardinaletti, Anna, and Michal Starke. 1996. Deficient pronouns-A view from Germanic: a study in the unified description of Germanic and Romance. In Studies in comparative Germanic syntax, Vol. II, eds. Höskuldur Thráinsson, Samuel David Epstein, and Steven Peter, 21-65. Dordrecht: Kluwer.

Chomsky, Noam. 1974. The Amherst lectures. Université Paris VII, Paris: Département de Recherches Linguistiques.

Chomsky, Noam. 2001. Derivation by phase. In Ken Hale: a life in language, ed. Michael Kenstowicz, 1-52. Cambridge: MIT Press.

Cinque, Guglielmo. 2002. Complement and adverbial PPs: implications for clause structure. Paper presented at the 25th generative linguistics in the old world conference, April 9-11, in Amsterdam and Utrecht.

Corver, Norbert. 2006. Freezing effects. In The Blackwell companion to syntax, Vol. II, eds. Martin Everaert and Henk van Riemsdijk, 383-406. Malden: Blackwell.

Culicover, Peter W., and Kenneth Wexler. 1977. Some syntactic implications of a theory of language learnability. In Formal syntax, eds. Peter W. Culicover, Thomas Wasow, and Adrian Akmajian. 7-60. New York: Academic Press.

de Haas, Wim, and Mieke Trommelen. 1993. Morfologisch handboek van het Nederlands: een overzicht van de woordvorming. The Hague: SDU Uitgeverij.

de Rijk, Rudolf. 1967. Object incorporation in Tongan and Dutch. Unpublished ms., MIT.

den Dikken, Marcel. 1995. Particles: on the syntax of verb-particle, triadic, and causative constructions. New York: Oxford University Press.

Evers, Arnold. 1975. The transformational cycle in Dutch and German. PhD dissertation, Utrecht University.

Evers, Arnold. 2003. Verbal clusters and cluster-creepers. Ms., Utrecht University.

Fox, Danny, and Jon Nissenbaum. 1999. Extraposition and scope: a case for overt QR. In Proceedings of the west coast conference on formal linguistics 18, eds. Sonya Bird, Andrew Carnie, Jason D. Haugen, and Peter Norquest, 132-144. Somerville: Cascadilla Press.

Franks, Steven. 1990. Case, configuration and argumenthood: reflections on the second dative. Russian Linguistics 14: 231-255.

Frey, Werner, and Karin Pittner. 1998. Zur Positionierung der Adverbiale im deutschen Mittelfeld. Linguistische Berichte 176: 489-534.

Guéron, Jacqueline. 1980. On the syntax and semantics of PP-extraposition. Linguistic Inquiry 11: 637678.

Gussenhoven, Carlos. 1992. Sentence accents and argument structure. In Thematic structure: its role in grammar, ed. Iggy M. Roca, 79-105. Berlin: Foris.

Haegeman, Liliane, and Henk van Riemsdijk. 1986. Verb-Projection raising, scope, and the typology of rules affecting verbs. Linguistic Inquiry 17: 417-466.

Halle, Morris, and Jean-Roger Vergnaud. 1987. An essay on stress. Cambridge: MIT Press.

Helmantel, Marjon. 2002. Interactions in the Dutch adpositional domain. PhD dissertation, Leiden University.

Hinterhölzl, Roland. 2000. Licensing movement and stranding in the West Germanic OV languages. In The derivation of $\mathrm{VO}$ and $\mathrm{OV}$, ed. Peter Svenonius, 293-326. Amsterdam: John Benjamins.

Hoeksema, Jack. 1991. Complex predicates and liberation in Dutch and English. Linguistics and Philosophy 14: 661-710.

Hoeksema, Jack. 1993. Suppression of a word-order pattern in West Germanic. In Historical linguistics 1991: papers from the 10th international conference on historical linguistics, ed. Jaap van Marle, 153-174. Amsterdam: Benjamins. 
Hoekstra, Teun. 1979. The Freezing Principle and stranded prepositions. In Linguistics in the Netherlands, 1977-1979, eds. Wim Zonneveld and Fred Weerman, 321-335. Dordrecht: Foris.

Hoekstra, Teun. 1984. Transitivity: grammatical relations in government-binding theory. Dordrecht: Foris. Hoekstra, Teun, Monic Lansu, and Marion Westerduin. 1987. Complexe verba. Glot 10: 61-78.

Hoekstra, Teun. 1988. Small clause results. Lingua 74: 101-139.

Hornstein, Norbert, and Amy Weinberg. 1981. Case theory and preposition stranding. Linguistic Inquiry 12: 55-94.

Horst, Jos. 1980. Preposition stranding in Dutch. Cornucopia I: 85-97.

Kayne, Richard S. 1984. Connectedness and binary branching. Dordrecht: Foris.

Kayne, Richard S. 1994. The antisymmetry of syntax. Cambridge: MIT Press.

Koopman, Hilda, and Dominique Sportiche. 1991. The position of subjects. Lingua 85: 211-258

Koster, Jan. 1973. PP over V en de theorie van Jan Emonds. Spektator 2: 294-311.

Koster, Jan. 1974. Het werkwoord als spiegelcentrum. Spektator 3: 601-618.

Koster, Jan. 1975. Dutch as an SOV language. Linguistic Analysis 1: 111-136.

Koster, Jan. 1978. Locality principles in syntax. Dordrecht: Foris.

Koster, Jan. 1987. Domains and dynasties. Dordrecht: Foris.

Koster, Jan. 1994. Predicate incorporation and the word order of Dutch. In Paths toward universal grammar: studies in honor of Richard S. Kayne, eds. Guglielmo Cinque, Jan Koster, Jean-Yves Pollock, Luigi Rizzi, and Raffaella Zanuttini, 255-277. Washington: Georgetown University Press.

Koster, Jan. 1999. The word orders of English and Dutch: collective vs. individual checking. In Groninger arbeiten zur germanistischen linguistik, ed. Werner Abraham, 1-42. Groningen: University of Groningen.

Koster, Jan. 2000. Pied piping and the word orders of English and Dutch. In NELS 30: proceedings of the north east linguistic society, eds. Masako Hirotani, Andries Coetzee, Nancy Hall, and Ji-yung Kim, 415-426. Amherst: GLSA.

Larson, Richard. 1990. Double objects revisited: reply to Jackendoff. Linguistic Inquiry 21: 589-632.

Matushansky, Ora. 2005. Call me Ishmael. In Proceedings of sinn und bedeutung 9, eds. Emar Maier, Corien Bary, and Janneke Huitink. 226-240. Nijmegen: NCS.

Müller, Gereon. 1995. A-bar syntax; a study in movement types. Berlin: Mouton de Gruyter.

Müller, Gereon. 1997. Extraposition as remnant movement. In Rightward movement, eds. Dorothee Beerman LeBlanc and Henk van Riemsdijk, 215-246. Amsterdam: John Benjamins.

Neeleman, Ad. 1994. Complex predicates. PhD dissertation, Utrecht University.

Neeleman, Ad, and Tanya Reinhart. 1998. Scrambling and the PF interface. In The projection of arguments: lexical and compositional factors, eds. Miriam Butt and Wilhelm Geuder, 309-353. Stanford: CSLI.

Pesetsky, David. 1995. Zero syntax: experiencers and cascades. Cambridge: MIT.

Reinhart, Tanya. 1995. Interface strategies. In OTS working papers in linguistics. Utrecht: OTS, Utrecht University.

Reinhart, Tanya. 1997. Interface economy: focus and markedness. In The role of economy principles in linguistic theory, eds. Chris Wilder, Hans-Martin Gärtner, and Manfred Bierwisch. 146-169. Berlin: Akademie Verlag.

Ross, John Robert. 1967. Constraints on variables in syntax. PhD dissertation, MIT.

Ruys, E.G. In preparation. Predicative complements, scrambling, and accent placement in Dutch. Ms., Utrecht University.

Schweikert, Walter. 2005. The order of prepositional phrases in the structure of the clause. Amsterdam: John Benjamins.

Simpson, Jane. 1983. Resultatives. In Papers in lexical-functional grammar, eds. Lori Levin, Malka Rappaport, and Annie Zaenen, 143-157. Bloomington: Indiana University Linguistics Club.

Stowell, Tim. 1982. Conditions on reanalysis. In MIT working papers in linguistics 4-papers in syntax, eds. Alec Marantz and Tim Stowell, 245-269. Cambridge: MIT Press.

Sturm, Arie, and Johan Kerstens. 1978. Over verklaren in de taalkunde. In Nieuwe Tegenstellingen op Nederlands taalgebied-Ruygh-bewerp VIII, eds. Peter van Putte and Henk J. Verkuyl, 130-172. Utrecht: Utrecht University.

van Riemsdijk, Henk. 1978. A case study in syntactic markedness: the binding nature of prepositional phrases. Lisse: Peter de Ridder Press.

van Riemsdijk, Henk, and Edwin Williams. 1986. Introduction to the theory of grammar. Cambridge: MIT Press.

van den Wyngaerd, Guido. 1989. Object Shift as an A-movement rule. In MIT working papers in linguistics 11: proceedings of the 1st student conference in linguistics, eds. Phil Branigan, Jill Gaulding, Miori Kubo, and Kumiko Murasugi, 256-271. Cambridge: MIT Press. 
Walraven, Frans. 1979. Vooropplaatsing en Accentuering van Pronomina in PPs. Gramma 3: 205-208

Winkler, Susanne. 1994. Secondary predication in English: a syntactic and focus-theoretical approach. PhD dissertation, Universität Tübingen.

Zwart, C. Jan-Wouter. 1992. SOV languages are head initial. Paper presented at the 8th comparative Germanic syntax workshop, November 20-22, in Troms $\varnothing$.

Zwart, C. Jan-Wouter. 1993. Dutch syntax: a minimalist approach. PhD dissertation, University of Groningen.

Zwart, C. Jan-Wouter. 1997. Morphosyntax of verb movement: a minimalist approach to the syntax of Dutch. Dordrecht: Kluwer.

Zwarts, Joost. 1997. Complex prepositions and P-stranding in Dutch. Linguistics 35: 1091-1112 